\title{
Kentsel Dönüşümün Nüfusun Sosyo-Ekonomik Yapısı Üzerindeki Etkileri: Ankara Yenimahalle Örneği *
}

\author{
The Effects on The Urban Socio-Economic Structure of The Urban Transformation: Ankara \\ Yenimahalle District
}

\author{
Mesut DOĞAN \\ Prof. Dr., Ístanbul Üniversitesi, Edebiyat Fakültesi, \\ Coğrafya Bölümü, esutan@istanbul.edu.tr \\ https://orcid.org/0000-0002-4926-5769
}

Makale Başvuru Tarihi / Received: 20.03.2019

Makale Kabul Tarihi / Accepted: 29.04.2019

Makale Türü / Article Type: Araştırma Makalesi

\author{
Hakan BOSTAN \\ Doktorant, Istanbul Üniversitesi, Sosyal Bilimler Enstitüsü, \\ Coğrafya Anabilim Dall, akadem118@yahoo.com \\ https://orcid.org/0000-0001-9376-0591
}

\section{ÖZET}

Kentsel alanlar, sürekli değişen ve yaşayan canlı sistem veya organizmalardır. Bu değişim kentleri fiziksel, sosyo-ekonomik ve kültürel yönlerden yeniden şekillendirmektedir. Türkiye'de kentsel dönüşüm olgusu fiziksel müdahaleler olarak algılanmakta, bunun kent nüfusunun sosyo-ekonomik yapısı üzerindeki etkisi ise

Anahtar

Kelimeler:

Kentsel Dönüşüm,

Gecekondu,

Kentlesme

Keywords:

Urban

Transformation,

Squatter,

Urbanization, yeterince incelenmemektedir. Bu değişim ve dönüşüm süreci Ankara üzerinden irdelendiğinde; kentsel alanda çarpık kentleşme ve gecekondulaşmanın etkisiyle büyük ölçekli toplumsal ve mekânsal dönüşüm yaşanmıştır. Kentsel dönüșüm konusunda ülkemizdeki ilk örnekler, 1980'lerin ikinci yarısında Ankara'da ortaya çıkmıștır. Türkiye'de sanayi sektörüne ucuz işgücü kaynă̆ sağlanması amacıyla, gecekondu alanlarına farklı bir politika ile yaklașılmış, bu bakış açısıyla imar af yasaları çıkarılmıştır. Ankara'da eski gecekondu alanlarına genellikle lüks konutlar yapılarak, orta ve üst gelir gruplarının oturduğu alanlar haline gelmiş, gecekonduda oturan alt gelir grubu nüfusun ise başka alanlara taşınmasına neden olmuştur. Bu çalışmada; Ankara Yenimahalle İlçesindeki kentsel dönüşüm projelerinden biri olan Macunköy, Pamuklar ve Mehmet Akif Ersoy Mahallelerindeki kentsel dönüşüm alanında dönüşümün nüfusun sosyo-ekonomik yapısı üzerindeki etkileri araştırılmıştır. Bu mahallelerde oturmaya devam eden eski gecekondu sahiplerinin oranının yaklaşık \% 7090'larda olması, bu projenin Ankara'da ve ülke genelinde daha önceki kentsel dönüşüm projelerinden farklılığı gösterilmiştir.

\begin{abstract}
Urban areas are the living system or organisms that are constantly changing and living. This change reshapes cities from physical, socio-economic and cultural aspects. The phenomenon of urban transformation is perceived as physical interventions, but the effect on the socio-economic structure of the urban population is not examined sufficiently in Turkey. When this process of change and transformation is examined through Ankara; large-scale social and spatial transformations were experienced with the effect of bad construction and squatters in the urban area. The first examples of urban transformation in Turkey came out in Ankara, the second half of the 1980s. To provide cheap labor in order to supply the industrial sector in Turkey, it has been approached with a different policy to the squatter housing areas, zoning amnesty laws were removed from this perspective. In Ankara, the old squatter areas are usually made up of luxury residences, which are the areas where the middle and upper income groups reside and the lower income group living in the squatter caused the population to move to other areas. In this study; the effects of urban transformation on the socio-economic structure of the urban transformation area of Macunköy, Pamuklar and Mehmet Akif Ersoy neighborhoods, one of the urban transformation projects in Ankara Yenimahalle District, are investigated. About 70-90\% of the old squatters who continue to live in these neighborhoods showed that this project was different from previous urban transformation projects in Ankara and throughout the country.
\end{abstract}

* Çalışma kapsamında Ankara Yenimahalle İlçesi'ndeki kentsel dönüşüm projelerinden birisi olan Macunköy, Pamuklar ve Mehmet Akif Ersoy Mahalleleri hakkında kentsel dönüşüm projeleri, raporları, proje ile ilgili plan, kroki, fotoğraflar konusunda yardımlarını esirgemeyen Yenimahalle Belediye Başkanı ile Kentsel Dönüşüm Müdürlüğ̈ personeli ile haritaların çiziminde Öğr.Gör.Fatih Adıgüzel'e teşekkür borçluyuz. 


\section{GIRIŞ}

Kentler canlı sistemler olup, zamanla; "sosyal gelişimdeki yetersizlik", doğal afetler, nüfus artışı veya "aşırı nüfus yı̆̆llmaları", "yanlış yer seçimi", kentleşmenin etkisi ile gecekondulaşma veya çarpık yapılaşma nedeniyle yıpranmaktadırlar (Şişman ve Kibaroğlu, 2009). Kentler, değişimler ve dönüşümler sayesinde de yenilenmektedirler. Kentsel alanlar dinamik yapısı gereği karmaşıktır. Kentsel alanlar, fiziksel, siyasi, çevresel, toplumsal ve ekonomik faktörlerin etkisiyle birlikte dönüşüm geçirirler.

Kentsel dönüşüm kavramı; "batıda 19. yüzyıldan itibaren uygulama alanı bulmaya başlamıştır" (Görgülü, 2008:769). Özellikle de II. Dünya Savaşı sonrasında savaşın yıkıcı etkisi sonucu kentsel dönüşüm yaygınlaşmıştır. 1950-1955 yılları Türkiye'de ilk sanayileşme faaliyetlerinin başladığı dönemdir. Sanayileşme sonrası artan nüfus ve iç göçlerin etkisiyle kentler büyümüş, kentleşme sorunları yaşanmaya başlanmıştır. Kentlerde yaşanan sağlıksız, çarpık ve plansız yapılaşma, çöküntü veya gecekondu alanlarının varlığı, yetersiz alt yap1 sorunları, tarihi mekânların ve ekonomik ömrünü tamamlamış yapıların varlığı kentsel dönüşümü gerekli kılmıştır. "Gerek arazi kullanım sürecinde gerekse beşeri bakımından şehirler sağlıklı büyüyememiş ve manevi değerler zarar görmüşse kentsel dönüşüm aynı zamanda bir şans olarak görülmelidir” (Doğan, 2018:3). Kentlerdeki gecekondu ve çarpık yapılaşma alanları, yeni konut ihtiyacını karşılamak maksadıyla, kentsel dönüşüme uğramaktadırlar.

Türkiye'de kırdan kente olan iç göçlerin ilk yaşandığı yerlerden olan Ankara'da, 1930'lu yıllar ile birlikte merkeze yakın alanlarda kaçak yapılaşma yani gecekondulaşma başlamıştır.

"Gecekondular başlangıçta göçe bağlı olarak oluşurken zaman içinde göçe neden olan baş unsur haline gelmiştir. Şehre iş için gelen halk daha sonra gecekonduda yerleşme olanağı bulunca önce barınma sonra iş sistemi içinde hareket etmeye başlamıştır. Böylece gecekondulaşma süreciyle şehirde estetik olmayan ve göze iyi görünmeyen bir yapı topluluğuyla karşılaşılmıştır" (Doğan, 2014:377).

Sanayi sektörüne ucuz işgücü kaynağı sağlaması nedeniyle gecekondu alanlarına farklı bir politika ile yaklaşılmış, bu bakış açısıyla imar af yasaları çıkarılmıştır. İmar afları sonucunda Ankara'da gecekondu sayısı hızla artmıştır. "Dünyada 1850'lerden ve Türkiye'de 1980'lerden itibaren kentsel dönüşüm projeleri gündeme gelmiştir" (Öngören, 2017:5). Kentsel dönüşüm konusunda ülkemizdeki ilk örnekler, 1980'lerin ikinci yarısında Ankara'da ortaya çıkmıştır. Bu süreç ile Ankara'nın fiziksel mekânı değişmiş, kentsel dönüşüm projeleri ile kendini yeniden üretmiş ve üretmeye devam etmektedir.

Araştırmada; ilk olarak, kavramsal çerçeve kapsamında konuyla ilgili olarak kent ve kentleşme kavramları hakkında bilgi verilmiş, kentsel dönüşüm kavramı ve uygulama biçimleri, yasal dayanaklar ile Türkiye'de kentsel dönüşüm süreci ele alınmıştır. Ankara'da gerçekleştirilen kentsel dönüşüm projeleri incelenmiş, gecekondu alanlarının olduğu Ankara Yenimahalle İlçesi'ndeki kentsel dönüşüm projelerinden biri olan Macunköy, Pamuklar ve Mehmet Akif Ersoy Mahalleleri örnek olarak seçilmiş ve kentsel dönüşüm alanında dönüşümün nüfusun sosyo-ekonomik yapısı üzerindeki etkileri üzerinde durulmuştur.

\section{VERI VE YÖNTEM}

Çalışmada yoğun olarak kentsel dönüşümün tarihi, çıkarılan ilgili yasalar ve gerçekleştirilen çalışmalar ile diğer konularda literatür araştırması gerçekleştirilmiştir. Ayrıca incelenen kentsel dönüşüm projesinin yasal, toplumsal ve ekonomik dinamiklerinin tespitinde, Yenimahalle Belediyesi yetkilileri, site yöneticileri, muhtar, emlakçılar ile site sakinlerinden bazılarıyla görüşmelerle bulunulmuştur. 


\section{KAVRAMSAL ÇERÇEVE: KENT VE KENTLEŞME KAVRAMLARI}

Kent; sosyo-ekonomik, politik, fiziksel ve kültürel boyutlarıyla sosyal bilimciler tarafindan farklı yönlerde tanımlanmıştır. Keleş (2013:102) kenti; “yerine ve zamanına göre geniş sayllabilecek biçimde bir araya gelmiş ve bir takım ayırt edici özellikleri bulunan insanlar ve yapılar topluluğu" şeklinde tanımlamıştır. Çavuşoğlu (2014:12) de kent kavramın;; "Kent kolayca okunamayan, denetlenemeyen, öngörülemeyen ve tasarlanamayan karmaşık iliş̧kiler ă̆ıdır ... kent, karmaşık iliş̧kilerin gömülü olduğu bir toplumsal mekân", olarak tanımlamıştır. Yine Tekeli (2011:18) kenti; "belli bir tarım dışı üretim, büyüklük, yoğunluk, heterojenlik ve bütünleşme düzeyine varmış ya da bu düzeyi aşmış insan yerleşmeleri" şeklinde tanımlamıştır. Hasol (1998) kenti, "nüfusunun çoğu ticaret, sanayi, hizmet veya yönetimle ilgili işlerle uğraşan, genellikle tartmsal etkinliklerin olmadiğı yerleşim alanları" ifadesiyle kentin sözlük anlamını belirtirken, Yıldırım (2004:8) ise, kente, fiziki ve fonksiyonel açılardan açıklama getirmiştir. Bu haliyle kenti; "fiziki açıdan kentler, farklı işlevdeki binalar ve insanların ulaşım ăğ olan yollardan oluşur. Fonksiyonel açıdan kent ise ekonomik, sosyal ve kültürel faaliyetlerin, aktivitelerin gerçekleştirildiği yerleşim birimleridir", şeklinde ifade etmiştir. Coğrafya açısından en geniş anlamıyla kent veya şehir; "merkezi özelliğe sahip, kalabalık bir nüfusu barındıran, tarım dışı üretimin geliştiği, kendine has yaşam tarzı olan planl yerleşmeler" olarak tanımlanır (Özdemir, 2016:86).

Tekeli (2011:20) kentleşmeyi; “bir yerleşmede ya da ülkenin yerleşmelerinde tarımsal olmayan üretim oranının artması ve tüm üretimin denetim ve koordinasyonunun yoğunlaşması sonucu büyüklük, yoğunluk, heterojenlik, bütünleşme derecelerinin artması olayı" olarak tanımlamıştır. Kentleşme veya şehirleşme, modern hayatın bir süreci olması yanında, sosyal alanda değişimlere de neden olmuştur. Kentsel dönüşüm de bu aşamada sosyal yapıda değişimlere yol açmıştır. Şehirlerde uygulanan kentsel dönüşüm projeleri insanları birbirinden uzaklaştıran projeler olabilmekte ve "toplumda istenmeyen sosyo-kültürel etkiler" oluşturabilmektedirler (Doğan, 2012:263; Doğan, 2018:7).

Türkiye'de ilk sanayileşme faaliyetlerinin 1950-1955 yıllarıyla birlikte başlamasıyla birlikte, ulaşım koşullarında yaşanan iyileşmeler, tarımda makineleşme, toprağın belli kişilerde birikmesi vb. faktörler sonucunda kırdan kente doğru iç göçler yaşanmaya başlamıştır. İç göçler 1955-1960 yıllarında da artışını sürdürmüştür. Bu süreci hızlandıran faktörleri ise tarımda düşük üretkenlik, köylerde oluşan işsizlik, eğitim ihtiyacı ve nüfus artışı oluşturmuştur (İçduygu ve Ünalan, 1998:43). Türkiye'de 1950'li yıllarda kırdan kente doğru iç göçlerin yaşanmasıla birlikte değişik sektörlerde üretim yapan fabrikalar kurulmuş ve hızlı sanayileşmeyle birlikte kentleşme olgusu yaşanmaya başlanmıştır (Sertkaya Doğan, 2009:3).

Batı ülkelerinde sanayiye bağlı olarak yaşanan iç göçler, Türkiye'de sanayiye bağlı olmadan gerçekleşmiş olup, yeterli endüstri olmaması sebebiyle kentleşme sanayileşme olmadan gerçekleşmiştir (Karpat, 2003:45). 19601980 yıllarında iç göçlerin devam etmesiyle birlikte kentlerin nüfusu artmış, bu durum ise hızlı kentleşmenin yaşanmasına neden olmuştur. Sanayileşen Türkiye, kentlere akan kırsal nüfusa barındırabilecek konut ihtiyacını sağlayamamış ve bu durum gecekondulaşmaya neden olmuştur (İçduygu vd., 2004:180). Kentlerde; plansız ve düzensiz yerleşme faaliyetleri olan gecekondulaşmayla birlikte, yüksek nüfus artışı yaşanmaya başlanmış, nüfusun beklenmeyen artışı ise işsizlikle birlikte altyapı ihtiyaçlarının karşılanmasında yetersiz kalınmasına neden olmuştur (Sertkaya Doğan, 2017:57). Kırdan kente yaşanan iç göçlerin devam etmesinde; kır-kent gelir dağılımının artması, kentlerin toplumsal ve ekonomik çekiciliğinin artması, ilk göç ile ortaya çıkan göçmen ağlarının yarattığı olumsuz etki, iletişim ve ulaşım alanındaki gelişmeler önemli rol oynamıştır (Bostan, 2017:6). Ankara ve İzmir metropol illeri ile İstanbul megapol ilin ilk oluştuğu dönem olmuştur. Bu çalışmanın konusunu oluşturan; Ankara İli de metropol olarak gecekondulaşma ve "kentleşme" sorunlarını yaşamış ve yaşanan bu sorunlar kentsel dönüşüm süreci ile giderilmeye çalışılmıştır. 


\section{KENTSEL DÖNÜŞÜM}

Türk Dil Kurumu Türkçe Sözlüğü, dönüşüm kelimesini, "olduğundan başka bir biçime girme, başka bir durum alma, şekil değiştirme tahavvül, inkılâp, olarak, transformasyon", kentsel dönüşümü ise; "kentin imar planına uymayan, ruhsatsız binaların yıkılıp, planlara uygun olarak toplu yerleşim alanlarının oluşturulması" olarak tanımlamaktadır (TDK, 2019). Özden (2002:14; 2006:217) kentsel dönüşümü;

"zaman süreci içerisinde eskiyen, köhneyen yıpranan ya da potansiyel arsa değeri mevcut üst yapı değerinin üzerinde seyreden ve çoğu kez yaygin bir yoksunluğun hüküm sürdüğ̈̈ kent dokusunun, alt yapısının sosyal ve ekonomik programlar ile oluşturulduğu bir stratejik yaklaşım içinde, günün sosyo-ekonomik ve fiziksel şartlarına uygun olarak yenilenmesi, değiştirilmesi, geliş̧tirilmesi, yeniden canlandırlmast ve bazen de yeniden oluşturulması eylemi",

şeklinde tanımlamıştır. Başka bir tanımda ise kentsel dönüşüm; "kentsel sorunların çözümünü sağlayan ve değişime uğrayan bir bölgenin ekonomik, fiziksel, sosyal ve çevresel koşullarına kalıcı bir çözüm sağlamaya çalışan kapsamlı bir vizyon ve eylem" olarak ifade edilmiştir (Thomas, 2003:15).

En geniş anlamı ile kentsel dönüşüm; "kentsel alanların gecekondu gelişimiyle dönüştürülmesi, kentsel saçaklanma bölgelerinin toplu konut alanı olarak gelişstirilmesi, çöküntü bölgelerinin yeniden yapılandırılması veya tarihi kent merkezlerinin korunmast ve canlandirlması gibi gerek fiziksel gerek toplumsal boyutları birlikte içeren dönüşüm biçimleri” olarak ifade edilmiş̧ir (Ataöv ve Osmay, 2007:57).

Kentsel dönüşümün uygulama biçimleri; yenileme (renovation-renewal), sağliklaştırma veya rehabilitasyon (rehabilitation), yeniden canlandırma (reviwal-revitalization), koruma (conservation), yeniden geliştirme (redevelopment), temizleme (clearance) veya alansal temizleme (urban clearance), düzenleme (improvement), boşlukları doldurarak geliştirme (infill development) veya yeniden geliştirme (redevelopment), tazeleme parlatma (refurbishment) ve yeniden inşaa etme (Reconstruction) (Açıkgöz, 2014; Şişman ve Kibaroğlu, 2009) şeklinde başlıklar altında toplanmıştır. Belirtilen çok farklı uygulama biçimlerin tanımında, farklı ülkelerde bu konuda çalışan bilim adamlarının yaptıkları tanımların Türkçeye çevrilmesi veya uyarlanmasındaki farklılıktan kaynaklandığı değerlendirilmektedir (Ertaş, 2011:4; Öngören, 2017:13).

Soylulaştırma (gentrification) kavramı da sık kullanılan bir kavram olup, uygulama biçimi veya yönteminden çok ortaya çıkan bir sonuçtur. Soylulaştırma; "kentlerde yaşayan düşük gelirli grupların, konutların yenilenmesi sonucunda yaşam koşullarında görülen değişim sonrasında orta ve üst gelirli gruplarla zorunlu olarak yer değiştirmesi olayı" (Çeker ve Belge, 2015:85) veya başka bir tanımla; "dar gelirlilerin yaşadı ğı, kent içerisinde köhneleşmekte olan konut alanlarına, daha üst sinıfların yerleşmeye başlaması süreci" (İslam ve Ciravoğlu, 2006:37) olarak belirtilmiştir.

Kentsel dönüşümün uygulama biçimleri konu gereği çok detaylı olarak açıklamak yerine kavramlar kısaca açıklanmıştır: Kentsel koruma; "yeni düzende eski çevreyi koruma", geliştirme; "rehabilitasyon olma özelliğini kaybetmiş alanlara yeniden farklı özellikler kazandırılması", canlandırma veya yeniden canlandırma; "özelliğini (sosyal, kültürel ve tarihi) kaybetmiş kent alanlarının eski durumuna getirilmesi", yenileme veya yeniden oluşturma; "eskimiş ve güvenli olamayan yapıların yerine yenisinin yapılması", rehabilite etme veya sağlıklaştırma; "zamanla müdahalelere uğramış ancak özgünlügünü kaybetmemiş yapıları eski haline dönüştürme" ve temizleme veya alansal temizleme; "yoksul alanların yeni çehreye dönüş̧ürülmesidir" (Doğan, 2018:3).

Türkiye'de gerçekleşen kentsel dönüşüm yasaları ile Türkiye'nin geçirdiği kentsel dönüşüm süreci bir sonraki bölümlerde detaylı olarak açıklanacaktır.

\subsection{Kentsel Dönüşüm Yasaları}

Dünyada kentsel dönüşüm ilk kez 1850'li yıllardan itibaren Batı Avrupa'da görülmeye başlanmıştır. Osmanlı İmparatorluğu'nda ise 1848 yılında ilk kez İstanbul için imar ve bayındırlık işlemleri için Ebniye Nizamnamesi (Yapılar Tüzügünü), sonrasında da 1864 yılında tüm İmparatorlukta uygulanmasını kapsayacak olan "Turuk ve Ebniye Nizamnamesi (Yollar ve Yapılar Tüzüğü)" ile 1882 yılında da Osmanlı döneminin ilk imar kanunu olan Ebniye Kanunu çıkartılmıştır (Doğan, 2018:4).

Kurtuluş savaşı sonrasında büyük bir yangın geçirmiş ve büyük ölçüde yangından etkilenen İzmir için 1924 yılında çıkarılan imar planı Cumhuriyet döneminin de ilk imar planıdır. Ankara şehri özelinde de 15/3/1924 
DOĞAN, Mesut ve BOSTAN, Hakan - Kentsel Dönüşümün Nüfusun Sosyo-Ekonomik Yapısı Üzerindeki Etkileri: Ankara Yenimahalle Örneği

tarihli ve 417 sayılı Ankara Şehremaneti Kanunu, 24/5/1925 tarihli ve 583 sayı1ı "İstimlak" kamulaştırma yasası olarak bilinen "Ankara'da İnşası Mukarrer Yeni Mahalle İçin Muktazi Yerler ile Bataklık ve Merzaği Erazinin Şehremanetince İstimlâki Hakkında" Kanun yayımlanmış ve 28/5/1928 tarihli ve 1351 sayılı yasa ile "Ankara Şehri İmar Müdürüyeti ve Teşkilat ve Vazifelerine Dair Kanun" ile Ankara'nın imar planı gerçekleştirilmiştir. Aynı zamanda 14/6/1948 tarihli ve 5218 sayılı "Ankara Belediyesine, Arsa ve Arazisinden Belli Bir Kısmını Mesken Yapacaklara 2490 Sayılı Kanun Hükümlerine Bağlı Olmaksızın ve Muayyen Şartlarla Tahsis ve Temlik Yetkisi Verilmesi Hakkında Kanun" Türkiye'de çıkarılan ilk gecekondu affı kanunudur. Türkiye'deki imar düzenlemeleri ile kentsel dönüşümün yasal dayanakları kronolojik sırayla aşağıda belirtilmiştir:

- 3/4/1930 tarihli ve 1580 sayılı Belediye Kanunu (bütün belediyelere imar yapma zorunluluğu getiren),

- 28/6/1948 tarihli ve 5228 sayılı Bina Yapımını Teşvik Kanunu,

- 6/6/1949 tarihli ve 5431 sayılı Ruhsatsız Yapıların Yıktırılmasına ve 2290 sayılı Belediye Yapı ve Yollar Kanununun 13 üncü Maddesinin Değiştirilmesine Dair Kanun,

- 24/7/1953 tarihli ve 6188 sayılı Bina Yapımını Teşvik ve İzinsiz Yapılan Binalar Hakkında Kanun,

- 9/7/1956 tarihli ve 6785 say1li İmar Kanunu,

- 9/5/1958 tarihli ve 7116 sayılı İmar ve İskan Vekaleti Kuruluş ve Vazifeleri Hakkında Kanun (ülkenin bölge, şehir, kasaba ve köylerin harita ve iskan planlarını hazırlama yetkisi imar ve iskan vekaletine verilmesi),

- 21/7/1959 tarihli ve 7367 sayılı Hazineden Belediyeye Devredilecek Arazi ve Arsalar Hakkında Kanun,

- 5/9/1963 tarihli ve 327 sayılı İmar Kanununa Geçici Bir Madde Eklenmesi Hakkında Kanun,

- 23/6/1965 tarihli ve 634 sayılı Kat Mülkiyeti Kanunu (kentteki ruhsatlı konutların yıkılarak çok katlı konutlara dönüşümünü sağlayan),

- 20/7/1966 tarihli ve 775 sayıl1 Gecekondu Kanunu (mevcut gecekonduların 1slahı, tasfiyesi ve yeniden gecekondu yapımını önleyen ve bu amaçlar doğrultusunda tedbirler getiren),

- 29/4/1969 tarihli ve 1164 sayılı Arsa Üretimi ve Değerlendirilmesi Hakkında Kanun,

- 11/7/1972 tarihli ve 1605 sayılı 6785 sayılı İmar Kanununda Bazı Değişiklikler Yapılması Hakkında Kanun,

- 16/3/1983 tarihli ve 2805 sayılı İmar ve Gecekondu Mevzuatına Aykırı Yapılara Uygulanacak Bazı İşlemler ve 6785 sayılı İmar Kanununun Bir Maddesinin Değiştirilmesi Hakkında Kanun,

- 21/7/1983 tarihli ve 2863 sayılı Kültür ve Tabiat Varlıklarını Koruma Kanunu,

- 4/11/1983 tarihli ve 2942 sayılı Kamulaştırma Kanunu,

- 13/12/1983 tarihli ve 180 sayılı Bayındırlık ve İskan Bakanlığı'nın Teşkilat ve Görevleri Hakkında KHK (İmar ve İskan Bakanlı̆̆ı'nın Bayındırlık Bakanlığı ile birleştirilmesi),

- 24/2/1984 tarihli ve 2981 sayılı İmar ve Gecekondu Mevzuatına Aykırı Yapılara Uygulanacak Bazı İşlemler ve 6785 sayılı İmar Kanununun Bir Maddesinin Değiş̧irilmesi Hakkında Kanun (imar ve gecekondu mevzuatına aykırı olarak inşa edilmiş ve inşa halindeki bütün yapılar hakkında uygulanacak işlemleri düzenleyen),

- 2/3/1984 tarihli ve 2985 say1l Toplu Konut Kanunu,

- 27/6/1984 tarihli ve 3030 sayılı Büyükşehir Belediyelerin Yönetimi Hakkında Kanun Hükmünde Kararname'nin Değiştirilerek Kabulü Hakkında Kanun,

- 27/11/1984 tarihli ve 3086 sayılı Kiyı Kanunu,

- 3/5/1985 tarihli ve 3194 sayıl1 İmar Kanunu,

- 23/7/1995 tarihli ve 4123 sayılı Tabii Afet Nedeniyle Meydana Gelen Hasar ve Tahribata İlişkin Hizmetlerin Yürütülmesine Dair Kanun,

- 24/4/2001 tarihli ve 4650 sayılı Kamulaştırma Kanununda Değiş̧iklik Yapılması Hakkında Kanun, 
- 4/4/2004 tarihli ve 5104 sayılı Kuzey Ankara Girişi Kentsel Dönüşüm Projesi Kanunu ve Yönetmeliği,

- 5/5/2004 tarihli ve 5162 sayıli Toplu Konut Kanununda ve Genel Kadro ve Usulü Hakkında Kanun Hükmünde Kararnamenin Eki Cetvellerin Toplu Konut İdaresi Başkanlığı'na Ait Bölümünde Değişiklik Yapılması Hakkında Kanun,

- 10/7/2004 tarihli ve 5216 say1lı Büyükşehir Belediye Kanunu,

- 16/6/2005 tarihli ve 5366 sayılı Yıpranan Tarihi ve Kültürel Taşınmaz Varlıkların Yenilenerek Korunması ve Yaşatılarak Kullanılması Hakkında Kanun,

- 3/7/2005 tarihli ve 5393 sayılı Belediye Kanunu ve "Kentsel Dönüşüm ve Gelişim Alanı" başlıklı 73. Maddesi,

- 18/6/2010 tarihli ve 5999 sayılı Kamulaştırma Kanununda Değişiklik Yapılmasına Dair Kanun,

- 29/6/2011 tarihli ve 644 sayılı Çevre ve Şehircilik Bakanlığı'nın Teşkilat ve Görevleri Hakkında KHK,

- 19/4/2012 tarihli ve 6292 sayılı Orman Köylülerinin Kalkınmalarının Desteklenmesi ve Hazine Adına Orman Sınırları Dışına Çıkarılan Yerlerin Değerlendirilmesi ile Hazineye Ait Tarım Arazilerinin Satışı Hakkında Kanun,

- 16/5/2012 tarihli ve 6306 sayılı Afet Riski Altındaki Alanların Dönüştürülmesi Hakkında Kanun,

- 16/5/2012 tarihli ve 6306 sayılı Afet Riski Altındaki Alanların Dönüştürülmesi Hakkında Kanunun bazı maddelerini iptal eden veya değiştiren Anayasa Mahkemesinin 27/2/2014 Tarihli ve E: 2012/87, K: 2014/41 Sayıl1 Karar1,

- 12/11/2012 tarihli ve 6330 sayılı On Üç İlde Büyükşehir Belediyesi ve Yirmi Yedi İlçe Kurulması Kanunu,

- 26/4/2016 tarihli ve 6704 sayılı 6306 sayılı Afet Riski Altındaki Alanların Dönüştürülmesi Hakkında Kanunun Anayasa Mahkemesi tarafından iptal edilen bazı maddelerin yeniden düzenlenmesini içeren kanun,

- 11/5/2018 tarihli ve 7143 sayılı Vergi ve Diğer Bazı Alacakların Yeniden Yapılandırılması ile Bazı Kanunlarda Değişiklik Yapılmasına İlişkin Kanun (3194 sayılı İmar Kanununa Geçici Madde Eklenmesi) oluşturmaktadır.

5104 sayılı "Kuzey Ankara Girişi Kentsel Dönüşüm Projesi Kanunu” kentsel dönüşümle ilgili doğrudan çıkarılan ilk kanun, 5162 sayılı Toplu Konut Kanununda değişiklik yapılması hakkında kanun ise, Toplu Konut İdaresi Başkanlığı'nın (TOKİ'nin) kentsel dönüşümde yetkili kılınmasını sağlayan kanun değişikliğidir. 7143 sayılı "Vergi ve Diğer Bazı Alacakların Yeniden Yapılandırılması ile Bazı Kanunlarda Değişiklik Yapılmasına İlişkin Kanun" ile 3194 sayılı İmar Kanununa geçici madde eklenmesiyle yeni imar affı kanunu yasalaşmıştır. Söz konusu geçici madde ile 31 Aralık 2017 tarihinden önce yapılmış yapılara, kentsel dönüşüm uygulamasına veya yapının yeniden yapılmasına kadar geçerli olan "Yapı Kayıt Belgesi” verilmesi öngörülmüştür. Bu uygulama ile gecekondu alanlarının ıslah sürecinin hızlandırılması gerçekleşebilecektir.

Türkiye'de kentsel dönüşüm sürecini, kamu adına Çevre ve Şehircilik Bakanlığı'na bağlı olan Toplu Konut İdaresi Başkanlığı (TOKİ) gerçekleştirmektedir. "2002 yılından itibaren, merkezi yönetim yaptığı yasal düzenlemelerle konut sektörü ve düzenli kentleşmeyi ön plana çıkarmış, yerel yönetimler (belediyeler) ve Toplu Konut İdaresi Başkanlığı'nı (TOKİ'yi) konut ve kentsel dönüşüm konularında baş aktör konumuna getirmiş, TOKİ, özel sektör ve yerel yönetimlerin işbirliğiyle gerçekleştirilen büyük ve kapsamlı kentsel dönüşüm projelerinin önü açılmıştır" (Açıkgöz, 2014:4). 1990 yıllarından itibaren uygulanan projelerde; yerel halk, sivil toplum örgütleri ve üniversiteler gibi katılımcıların yer aldıkları görülmektedir (Kalağan ve Çiftci, 2012:129130).

İkinci Dünya Savasından sonra liberalleşmeyle birlikte uygulanan politikalar, kentsel alanlardan kâr elde etmeye odaklanmış, yukarıda belirtilen, "bina yapımını teşvik" yasaları ya da gecekondu aflarıyla kentsel rantlar teşvik edilmiştir. "Kentsel arsa ve bina spekülatörlü̆̆̈̈, dönemin ticaret burjuvazisinin sermaye birikimini artırdiğ yatırım alanı olmuştur" (Akın, 2007:266). İmar ve gecekondu afları bir ölçüde kaçak yapılaşmayı teşvik etmiş ve özendirmiştir. Aynı zamanda 1984 yılında çıkarılan imar ve gecekondu affı ile birlikte devletin vatandaşları arasındaki eşitlik anlayışı zedelemiştir: "Devlet gecekondu yapmak yerine modern kesimden bir kat almış bir 
DOĞAN, Mesut ve BOSTAN, Hakan - Kentsel Dönüşümün Nüfusun Sosyo-Ekonomik Yapısı Üzerindeki Etkileri: Ankara Yenimahalle Örneği

ailenin çocuklarının konut sorununu düşünmezken, kentin iyi yerlerinde gecekondu yapmış olanların ikinci neslinin konut sorununu çözmeye çalışlyordu" (Tekeli, 2016:109).

Halen yürürlükte bulunan 3194 sayılı İmar Kanununun 7'nci maddesine göre, nüfusu 10.000 bini aşmayan yerleşmelerin imar planlarının yaptııılması mecburi değildir. Kentlerin büyümeye başlamadan imar planlarının yapılmas1 gerekmekte olup, sonrasında kentsel dönüşüm hem maliyetli olmakta hem de kolay gerçekleşememektedir. Bu nedenle yukarıda belirtilen nüfus sınırlandırılması gözden geçirilmeli, küçük belediyelerin ekonomik olarak destekleyecek yeni hükümler getirilmelidir. Yukarıda belirtilen çok çeşitli mevzuat ve yapılan eklemeler nedeniyle oluşan karmaşıklık, yeniden ele alınmalı ve oluşan çelişki ve yetki karışıklıkları yeniden düzenlenmelidir (Öngören, 2017:205-208).

\title{
4.2. Türkiye'de Kentsel Dönüşüm Süreci
}

İkinci Dünya Savaşı'ndan sonra Türkiye'nin metropol kentlerinin ilk dönüşüm örnekleri gecekondulaşma olmuştur. Türkiye'de kentsel dönüşüm, Ataöv ve Osmay (2007) tarafindan üç dönem halinde incelenmiştir:

• 1. Dönem “1950-1980: Hızlı Kentleşme ve Gecekondudan Apartmana Dönüş Süreci”.

1950 ve 1980 yılları arasında, ekonomik büyüme stratejisinin yaygınlaşması ve gelişen sanayileşmeyle birlikte köyden kente yaşanan iç göçler, getirdiği hızlı kentleşme, gecekondulaşma ve kentsel yoksulluk vb. olgular ile kentlerde bazı sosyo-ekonomik değişimlerin yaşanmasına yol açmıştır. "Bu dönemde en önemli kentsel dönüşüm kent çeperindeki boş arazilerin gecekondu mahallelerine dönüşmesi ve daha sonra bu mahallelerin sağlıklaş̧tırılması, apartmanlaşarak yeniden yapılandırılması veya temizlenerek farkl nüfus gruplarina yönelik kentsel yenilenmesi şeklinde olmuştur" (Ataöv ve Osmay, 2007:58). Aslında apartmana dönüş sürecinde insan faktörünün etkisi önemli rol oynamıştır: "Genelde yeni ve aparman tarzı yapılar özellikle genç nüfus arasında bir prestij unsuru olarak kabul edilmiş, yani gelişmiş ülkelerde restore edilen eski yapllarda oturmanın bir prestij unsuru saylmasinın tam tersi bir durum gözlenmiştir ülkemizde; insanlar önce daha rahat bir yaşamı arzu etmektedirler" (Özgüç, 1992:104).

- 2. Dönem “1980-2000: Kentiçi Ruhsatlı ve Ruhsatsız Yapılaşma Süreci”.

Büyük kentlerin liberal ekonomi ve küreselleşmeden etkilenmeye başladığı dönemdir.

\begin{abstract}
"Bu dönemde metropol kentlerde iki önemli gelişme gözlemlenmiştir. Bir yandan kent içinde ruhsatl ve ruhsatsı yapılanma meydana gelmiş, öte yandan yerleşim alanları merkez dışına yayılmıştır... Yaş̧am kalitesi düşen alanlar ile riskli alanların yenilenmesi, sağlıklaş̧ırılması (rehabilitasyonu) veya yeniden canlandırllması şeklinde olmuştur. Ayrıca, tarihi değeri olan alanların soylulaştırllarak korunduğu izlenir" (Ataöv ve Osmay, 2007: 59).
\end{abstract}

Türkiye‘de 1980 yılından sonra gerçekleşen kar amacı güden kentsel dönüşüm projeleriyle kentlerin gereksiz yayılmasına, tarihi, kültürel ve doğal güzelliklerin yıkımına, kamu kaynaklarının verimsiz kullanımına neden olmuş ve kutuplaşmayı artıran kentsel mekânlar yaratılmıştır (Öngören, 2017:9; Sekmen, 2007).

• 3. Dönem “2000 Sonrası: Kentsel Dönüşümün Yasallaşması Süreci”.

Yerel yönetimin, özel sektörle işbirliğini güçlendirdiği ve kentsel dönüşümün ilk defa "strateji” olarak belirlendiği dönemdir. "Ancak dönüşüm stratejisi sadece kentsel yenileme olarak tanımlanmış ve bu yaklaşım farklı kent parçalarının farklı kullanımlara dönüşı̈̈rülmesi için uygulanmaya başlanmıştır... Düşük nitelikli apartmanlarda daire sahipliği veya kiracılık yaygınlaşırken, özel sektör eliyle kent dışında lüks konut sitelerinin yapımı artmıştır. Kent merkezlerinde ise tarihi konut stoku yeni konut veya işyeri olarak kullanıma açılmaya devam etmiştir" (Ataöv ve Osmay, 2007:59, 69). 2000 yılı sonrasında kentsel dönüşüm stratejisi gecekondu alanlarından "kent makroformuna" olan yayılmasını devam ettirmektedir (Artuç, 2016:34). Bu süreçte ayrıca son çıkan kanunlardan olan 6306 sayılı Afet Riski Altındaki Alanların Dönüştürülmesi Hakkında Kanun ile birlikte Çevre ve Şehircilik Bakanlığı'na geniş yetkiler tanınmış olup, merkezi yönetime artan bir rol verilmiştir (Yenice, 2014:85).

Türkiye'de kentsel dönüşüm ilk aşamada; Ankara, İstanbul ve İzmir'de oluşan yasadışı konut alanlarının yeniden yapılandırılması şeklinde gerçekleşmiştir. Uygulamada bu alanların değer artışı ve değer paylaşımı yaklaşımıyla kentlerin fiziksel yapısının değiştirilmesi göz önünde bulundurulmuş, sosyal ve çevresel boyutları gözardı edilmiştir (Yenice, 2014:78). Kentsel dönüşüm, gelişen sağlıksız ve niteliksiz alanların yeniden yapılandırılmasını içermekle birlikte, ilk öncelik, bölge insanının sosyal ve ekonomik sorunlarının çözüme 
kavuşturulması olmalıdır.“ Kentsel dönüşüm; yıkım, temizlik, proje ve inşaatlarla değil, sosyal ve ekonomik kalkınmaya yönelik programlarla, mahallelilerin ortak ihtiyaç ve özelliklerine uygun, onları bütünleştirecek projelerle başlaması gereklidir" (Şişman ve Kibaroğlu, 2009). Meder ve Baydar (2018:216) Türkiye'deki kentsel dönüşüm sürecini; “Türkiye'deki uygulamalar mercek altına alındığında da görülür ki, kentsel dönüşüm ekonomik ve sosyal boyutları olmayan, katılımcllıktan tamamen uzak, mülksüz kılıcı ve dolaylsıyla yoksun ve yoksul kalıcı bir mekân müdahalesi olarak" belirtmişlerdir.

2000 y1lı sonrası kentsel dönüşüme bir örnek olarak; İstanbul ili Zeytinburnu İlçesi Sümer Mahallesi'nde kentsel dönüşümün etkisi üzerine, 2013 yılında 192 hane üzerinde derinlemesine mülakat yöntemiyle yapılan alan araştırması neticesinde, sunulan öneriler kapsamında; özellikle evlerin tasarımında kültürel yapının dikkate alınmasını (tuvalet/banyo türü, Amerikan mutfak vb.), balkonu bulunmayan dairelerin yapılmamasını, yapılan projelerde aile büyüklüğü ve mekân kullanımına göre planlama yapılmasını (1+1 dairelerin olmaması vb.), yeşil alanların artırılması gerektiği belirtilmiştir (Günaydın, 2015:106-107). Bu çalışmada, bölge insanının ortak ihtiyaç ve özelliklerine uygun, sosyal ve ekonomik kalkınmaya yönelik bir kentsel dönüşümün ortaya konulmadığı tespit edilmiştir.

Kentsel dönüşümün bazı alanlarda da büyük faydaları bulunmaktadır: "Ülkemizde uygulanan bazı alanlarda konutlar büyük parsellerde yapılmıştır. Bunun yanında cadde ve sokaklar daha geniş hale gelmiş, yüksek olan suç oranları düşmüş, bakımsız kalan tarihi binalar şehre yeniden kazandırılmıştır" (Doğan, 2018:6).

Kentsel dönüşüm projeleri fiziki, sosyo-ekonomik boyutlarıyla birlikte dengeli bir yapıda gerçekleştirilmelidir.

"Kentsel dönüşüm projelerinde alt gelir gruplarının yaşadiğı bölgelerde, kullanıcıları yerinden etmeyen, dışlamayan, kent yaşamının fiziki ve sosyo-ekonomik imkânlarından faydalanmasını sağlayacak, toplumsal yaşama bilinci içinde, ülke ekonomisine katkı sağlayacak planlamalar yapılarak dönüşüm uygulamaları dengeli bir yapıda gerçekleştirilmelidir" (Artuç, 2016:39).

Türkiye son elli yılda kentsel sorunların çözümüne yönelik uyguladığı kentsel dönüşüm projeleri, sorunun sadece fiziksel boyutlarına göre gerçekleşmiştir: "Bu yüzden, kentsel çevrenin dönüşümü, sosyal gelişim ekonomik kalkınma, çevre koruma ve demokratik örgütlenme ile birlikte bütüncül bir yaklaşımla gerçekleştirilmelidir" (Ataöv ve Osmay, 2007:73). Bu maksatla, kentsel dönüşümün kentin hassas alanlarında yapılması nedeniyle, planlamalarda; coğrafyacı, sanat tarihçi, sosyolog, psikolog, hukukçu, şehir plancısı, mimar, mühendis gibi farklı disiplinlerden oluşan mesleklerden oluşan bireylerin multidisipliner şekilde çalışması önem kazanmıştır (Demirkıran, 2008:100; Ertaş, 2011:3).

Kentsel dönüşüm projelerinin sürdürülebilirliği açısından; “Özel sektörün, sivil toplumların ve yerel halkın en temel aktörler olarak sürece dâhil edilmesinin gerekliliği, sürdürülebilirlik açısindan son derece önemlidir" (Kalağan ve Çiftçi, 2012:131). Kaya (2006:215) bu durumu; "kentlerin makro planlarının yapımından yani Kentlerin Yönetiminden başlayarak, halkın ve halkın örgütlü temsilcilerinin katılımı ciddi bir konudur, bu sağlanamadı̆̆ takdirde tüm projeler ve yatırımlar sağlıksız kentsel gelişmenin, israfin, kentsel yağmanin ve güçsüz kesimlerin ezilmesinin aracı olacaktır", şeklinde özetlemiştir.

Avrupa'da kentsel dönüşüm sürecinde toplum çıkarlarının, Türkiye'de ise ekonomik ve politik çıkarların ön planda olduğu Çakır (2006) tarafından gözlemlenmiş olup, çözüm noktasında şu önerilerde bulunmuştur:

"Çevresel kalite ve fiziksel iyileştirme dışında toplumun temel ihtiyacı olan sağllk birimleri, sosyal donatılar ve etkinlikler ayrıca, çeşitli kültürel etkinlikleri içerebilecek kamusal alanlar, proje kapsamında yer almalıdır. Yaşayan halkın becerilerini geliştirebileceği sosyal etkinlikler mutlaka dönüşüm programında yer almalıdır" (Çakır, 2006:120).

Türkiye'de kentsel dönüşüm projeleri insan merkezli olmalı, tarihi ve sosyo-kültürel değerleri dikkate almalı, bir rant kapısı olarak görülmemelidir. "Daha yaşanabilir, sağlıkll, güvenli ve altyapısı güçlü yerleşmelerle sosyo-kültürel değerleri koruyan ve sürdürülebilir bir gelecek için kentsel dönüşüm projeleri uygulanmalıdır" (Doğan, 2018:7). 


\subsection{Ankara ve Ankara'nın Kentsel Dönüşüm Süreci}

Türkiye Cumhuriyeti'nin başkenti olan Ankara, Türkiye'de planlı gelişen ilk kentlerden biridir (Göymen, 1997:70) (Harita 1). Ankara; "yalnızca orta boy bir Anadolu kasabasının batıl anlamda çağdaş bir kente dönüşürü̈lmesi değil, aynı zamanda doğulu bir toplumun batılı değerleri benimsemesi adına gerçekleştirilen bir modernleşme projesinin de mekâna yerleşmesi anlamı" da taşımaktadır (Şahin, 2006:112). Ankara'nın başkent olması ve başkente yaraşır bir imar planı ve çalışan memurların barınma ve iskân sorunları Cumhuriyetin ilanıyla birlikte gündeme gelmiştir. Bu maksatla; 16 Mart 1924 yılında 417 sayılı Ankara Şehremaneti (Belediyesi) Yasası ile özel mülkiyete ait alanların kamulaştırılması maksadıyla, 1925 yılında 583 sayılı "Ankara'da İnşası Mukarrer Yenimahalle için Merkezî Yerler ile Bataklık ve Mergazi Arazinin Şehremanetince İstimlâki Hakkında Kanun" çıkartılmıştır. Sonrasında belediyenin Ankara'nın imarında yeterli olmayacağı düşünülerek, 1928 yılında 1351 sayılı yasa ile merkezî yönetime bağlı olarak "Ankara Şehri İmar Müdürlügü̈" kurulmuştur. Sonrasında ise "Ankara Şehri İmar Müdürlüğü” 1937 yılında Ankara Belediyesine bağlanmıştır (Akın, 2007:157-160).

Harita 1: Ankara Lokasyon Haritas1

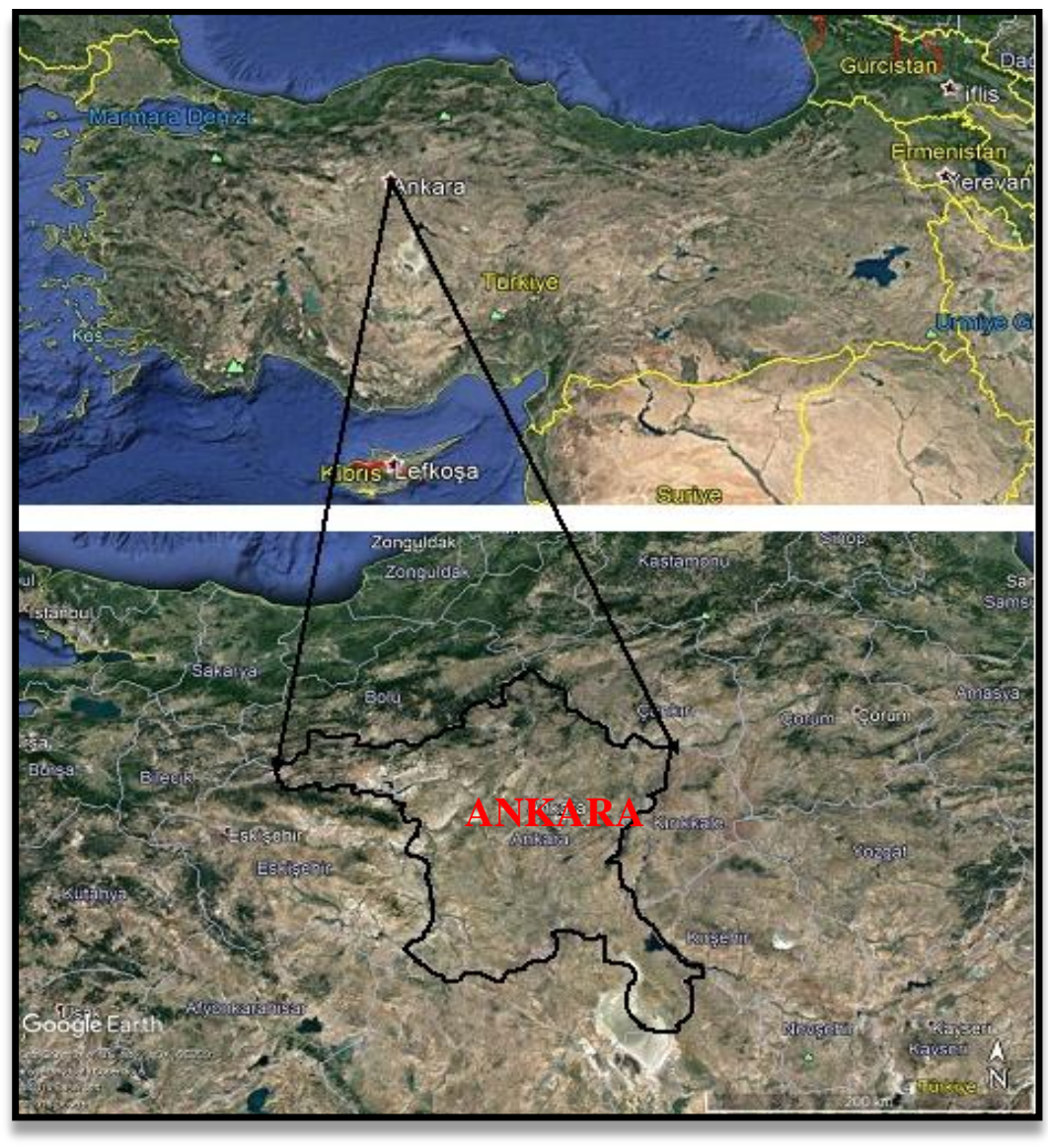

Kaynak: http://earth.google.com

Türkiye'de kırdan kente başlayan ilk göçler nedeniyle Ankara'da, 1930'lu yılların başından itibaren merkeze yakın alanlarda kaçak yapılaşma yani gecekondulaşma süreci başlamıştır. Başlayan gecekondulaşma sürecinin sonucunda, Ankara kenti özelinde geçerli olan 14/6/1948 tarihli ve 5218 say1l "Ankara Belediyesine, Arsa ve Arazisinden Belli Bir Kısmını Mesken Yapacaklara 2490 sayılı Kanun Hükümlerine Bağlı Olmaksızın ve Muayyen Şartlarla Tahsis ve Temlik Yetkisi Verilmesi Hakkında Kanun" ile ilk gecekondu af yasası çıkarılmıştır (Akın, 2007:174). 1957 yılında Ankara'daki gecekondu sayısı 45.850'ye ulaşmış ve bu gecekondularda ise 222.275 kişi yaşamaktaydı. Bu gecekonduların 795 adedine 1957 yılında, 29.345 adedine de sonraki bir yıl içerisinde tapu verilmiştir. 1963 tarihinde 327 sayıl1 6785 sayılı İmar Yasasına Geçici Bir Madde Eklenmesi Hakkında Kanunla bir kez daha imar yani gecekondu affı yasası çıkarılmış olup, Abidinpasa, Altındağ, Arifbey, Saimekadın çevresi, Telsizler ve Topraklık gecekondu alanları imara açılmıştır. Türkiye'de sanayi sektörüne ucuz işgücü kaynağı sağlaması nedeniyle, gecekondu alanlarına farklı bir politika ile 
yaklaşılarak imar af yasaları çıkarılmıştır. İmar afları sonucunda Ankara'da gecekondu sayısı hızla artmıştır. Ankara'da 1966 yılında gecekondu sayısı 100.000 kişiye, 1975 yılında ise 202.000 kişiye ulaşmıştır. 1970 yılında Ankara'nın \% 72'si, 1994 yılında ise \% 64'ü gecekondularda yaşamaktaydı (Keleş, 1984:358; Özgür, 1994:76).

Kentsel dönüşüm konusunda ülkemizdeki ilk örnekler, 1980'lerin ikinci yarısında Ankara'da ortaya çıkmıştır. Ankara'da gerçekleştirilen kentsel dönüşüm projelerinden 1989 yılında kamu ve özel sektör işbirliği, arsa sahipleri, proje ortaklığ 1 ve girişimcinin katılımını öngören ve arsa sahiplerinin temsilciler aracılığıyla şirket, yönetim ve denetim kurumlarında temsil edilmesi sağlanan, vadinin en az \% 70-80'inin yeşil alan olarak ayrılan, Ankara Büyükş̧ehir Belediyesi'nce gerçekleştirilen belli başlı uygulamaların ilk örneklerini; "kendi kaynağını kendi yaratan” proje olan Portakal Çiçeği Vadisi Kentsel Dönüştürme Projesi (1984-1989) ile belediye yöneticileri, şirket, proje ortaklı̆̆ 1 ve arsa sahiplerinin kooperatif kurarak örgütlendiği, girişimcinin katılımını öngören, aktörlerin temsilciler aracılığıyla proje kararlarına katılımı sağlanan Dikmen Vadisi Kentsel Dönüştürme Projesi (1989-1994) oluşturmaktadır (Bayram, 2006:9; Gümüşboğa, 2009:75; Özden, 2002:200; Yaman, 2011:176).

1990 Ankara Nazım Planı doğrultusunda yukarıda da belirtilen kentsel dönüşüm projeleri de dâhil olmak üzere;

- Sincan, Etimesgut Gecekondu Önleme Bölgeleri,

- Eryaman, Batıkent, Çayyolu konut alanları,

- Dikmen Vadisi (Deresi), İmrahor Vadisi (Çankaya Bağcılar, Kırkkonaklar vb.), Etlik-Kasalar, Portakal Çiçeği kentsel düzenleme (dönüşüm) projeleri olarak belirlenmiş ve bu plan doğrultusunda Ankara gelişmesini sürdürmüştür (Akın, 2007:192).

Kentsel dönüşüm projelerinin büyük bölümü gecekondu bölgelerinde yapılmaktadır. Ankara'da gecekondu bölgelerinde gerçekleştirilen gecekondu dönüşüm projelerinden diğerleri ise, GEÇAK I (Koza Sokak), GEÇAK II (İmrahor Vadisi veya Çankaya Belediyesi'nin Bağcılar, Kırkkonaklar, Çukurca'nın bir kısmını kapsayan bölge), Altındağ-Aktaş-Atilla Kentsel Dönüşüm Projesi, Yıldızevler Özel Proje Alanı, Yenimahalle Belediyesi Şirindere Kentsel Dönüşüm Projesi, Mamak Belediyesi Ege Kentsel Dönüşüm Projesidir. Kentsel dönüşüm projeleri 1980'lerin ikinci yarısıyla birlikte ortaya çıksa da, 2000'lerin başından itibaren önem kazanmaya başlamıştır. Ankara Güneypark Kentsel Dönüşüm ve Gelişim Projesi (2005 y1l1), Ulus Kent Tarihi Kent Merkezi Yenileme Alan Projesi (2005 yıl1), Çankaya Çukurambar Kentsel Dönüşüm ve Gelişim Projesi (20062009 yılları), Çayyolu Gordion Kaynak Temin Projesi (2007 y1lı), Batıkent II. Etap Batıpark Kaynak Temin Projesi (2007 y1l1), Atlantis AVM Kaynak Temini Projesi ve Kuzey Ankara Girişi (Protokol Yolu) Kentsel Dönüşüm Projesi 2000 yılı sonrası Ankara'daki belli başlı kentsel dönüşüm projeleridir (Yaman, 2011:176179).

Ankara, olumlu ve olumsuz tüm yönleriyle birlikte, "bir yandan, ilk modern kent planına, ilk yapı kooperatifine, ilk kamu konutlarına, ilk yaya bölgesine tanıklı ederken, bir yandan da ilk düzensiz kentleşmeye, ilk gecekonduya, ilk gecekondu affina ve ilk arsa vurgunculuğuna ev sahipliği”" (Keleş ve Duru, 2008:27) yapan ilklerin yaşandığ kentdir.

Ankara ili ilk imar planı yapılan ve planlı gelişen başkent olmakla birlikte, planlara uyulmaması nedeniyle de sağl1klı ve düzenli kentleşme gerçekleşmemiştir: "Belediyeler yaklaşık kırk yıldır imar planlarına uymayan yapılara göz yummuş, bir müddet sonra merkezde (Ankara'da) çizilen planları da değiş̧tirerek, yeşil alanları ve sosyal donatı alanlarını buralara da bina yapmak için planlardan kaldırmışlardır. Bu nedenlerle sağlıklı ve düzenli kentleşme gerçekleşememiştir" (Öngören, 2017:4).

Ankara ili Altındağ ilçesinin Çinçin olarak bilinen bölgede bulunan, 1955 yılından itibaren Ankara'nın ilk gecekondularından oluşan şehrin en yoksul ve alt gelir grubunun konut alanı olan Gültepe Mahallesi, 2007 yılında uygulanmaya başlanan kentsel dönüşüm öncesinde çöküntü bölgesine dönüşmüş veya slamlaşmıştır. Kentsel dönüşümün sosyo-ekonomik yapı üzerindeki etkisi ise;

"dayanı̧̧ma temelli hemşerilik ilişkilerinin çete ve suç üzerinden yürüyen çıkar ilişkilerine dönüstügü̈, sosyal karmaşa ile birlikte ortaya çıkan güvensiz ve karmaşık sosyal organizasyonun gündelik yaşamın bir parçası haline geldiği eski gecekondu mahallesinde, kentsel yaşamdan ve toplumsal kurumlardan tamamen kopuk, kendi enformel ilişkileri ve kuralları ile işleyen bir toplumsal yapı ortaya çıkmıştır" (Ersavaş, 2009:216).

Gültepe Mahallesi kentsel dönüşüm projelerinde 2013 yılına gelindiğinde ise nüfus artışıla birlikte nüfus yoğunluğu artmış, sosyal yapının değişimiyle birlikte; eğitim düzeyi, istihdam oranı ve gelir durumu 
yükselmiştir. Emlak değerlerinin yükselmesiyle birlikte de düşük gelirli mahalle sakinlerinin bölgeden taşınması ve yerlerine üst gelir grubunda bulunan ailelerin taşınması sonucunda mahallenin "soylulaştırma" süreci yaşanmıştır.

"Burada yaşanan yoksulluk ve güvenlik zafiyeti yerel idareyi uygulama yapmaya zorlamıştır. Ancak mahalle'de projeyle hedeflenen suç oranı ve yoksulluk azalmış ancak suç ve yoksulluk ortadan kalkmamış sadece gönülsüz terkin aktörleriyle birlikte mekân değiştirmiştir. TOKI projede bir inşaat firması gibi davranmış, katılımdan uzak bir planlama anlaylşıyla proje sakinlerince memnuniyetsizliklerin sıklıkla dile getirildiği mekânlar üretmiştir" (Açıkgöz, 2014:176).

Bu makalenin konusu olan kentsel dönüşümün nüfusun sosyo-ekonomik yapısı üzerindeki etkileri kapsamında; 1992 yılında koza sokakta GEÇAK I projesinde yüksek gelir gruplarının oturduğu bir alandaki 47 gecekondu sahibinin kurmuş olduğu Konut Kooperatifine belediye tarafindan 5 adet arsa tahsis edilmiş, belediye ile anlaşamaya varamayan gecekondu sahiplerine ise Çukurca ve Kırkkonaklar kentsel geliştirme bölgelerinden arazi verilmiş ve gecekondu sahipleri MESA'nın yaptığı konutlardan hak sahibi olmuşlardır. Gecekondu sahiplerinin büyük bir oranı, inşaatların tamamlanmasına müteakip konutlarında oturmayı tercih etmemiş, konutları ya kiraya vermiş ya da satmışlardır (Akın, 2007:208).

Ankara Dikmen Vadisi 3.Etap Kentsel Dönüşüm uygulaması kapsamında 60 kişiye anket uygulanarak yapılan bir çalışmada; önceden gecekondularda yaşayan insanların proje sonrası hak kaybına uğradığı ve mağdur edildiği, proje kapsamında yapılan 1,5 milyon TL değerinde özel güvenlikli lüks konutların inşa edildiği, hak sahiplerine ayrılan alanda 303 hak sahibinin bir kısmının elde ettiği konutlarını sattığı, bir kısmının ise kiraya vererek başka alanlara yerleştiği, sadece 174 kişinin konutlarda ikamet ettiği, bunların büyük bir kısmının ise kiracı olduğu, eskiden bölgede yaşayanların Ankara'nın başka yerlerine gittikleri, bu alanlarda yeni zenginler yaratıldığı, bölgenin soylulaştırıldığı, eski yerleşimcilerin kentle bütünleşme sürecinin amacına ulaşamadığ sonucuna varılmıştır (Yaman, 2011:250). Böyle bir kentsel dönüşüm projesinde de sosyo-kültürel değişimi görmek mümkün olmuştur.

Çıkarılan özel bir yasayla gerçekleştirilen Kuzey Ankara Girişi (Protokol Yolu) Kentsel Dönüşüm Projesi yoğun eleştirilere maruz kalmıştır. Eski ev sahiplerine yıkım süresince sağlanan maddi imkânların yetersiz olması, sözleşmelerin imzalanmasında sadece bilgilendirme yapılması ve halkın karar alma süreçlerine dahil edilmemesi bu eleştirilerin başlıcalarını oluşturmaktadır. Gümüş (2006:58'den akt.: Gümüşboğa, 2007:76), Baraj Mahallesi Muhtarı Arif Gümüş ile yapılan mülakat da önceden kimsenin arsa sahiplerine bilgi verilmediği, sonrasında gönderilen dilekçelere ise cevap verilmediği ve hak sahipliği konusunda arsa sahiplerinin sorunlar yaşadığı hususları tespit edilmiştir. Kuzey Ankara Girişi Kentsel Dönüşüm Projesi aynı zamanda hak sahiplerinin görüşü doğrultusunda katılımcı bir yaklaşımla gerçekleşmemiş olup, sonucunda ise "bölge halkının yaşam tarzına uygun olmayan ev mimarisi yapılmış, gelir düzeyleri, gelir getiren faaliyetleri, sosyal iliş̧ki ve yaşantıları dikkate alınmayarak yeni bir dünya oluşturulmuştur" (Doğanay, 2016:103).

Kentsel dönüşüm projeleri; eski gecekondu alanlarına genellikle lüks konutlar yapılarak, orta ve üst gelir gruplarının oturduğu alanlar haline gelmekte, gecekonduda oturan alt gelir grubu nüfusun ise başka alanlara taşınmasına neden olmaktadır. Ankara'da kentsel dönüşüm projeleri ile gecekondu alanlarında oturanları konut sahibi yapmak amacı güdülmesine rağmen, gecekondu sahipleri kendilerine verilen yüksek değerdeki konutlarda oturmayı tercih etmemekte, düşük maliyetli yeni bir konut yapmanın yollarını aramakta ya da alıştığı yaşam kültürünün yeni mekânında yaşamayı zorlaştırması nedeniyle, kendi kültürü ile yaşayabilecekleri bir yere taşınmayı tercih etmektedirler (Akın, 2007:260).

Islah imar planları "gecekondu alanlarını düzenli konut stokuna dönüştürmeyi amaçlamaktadır" (Ataöv ve Osmay, 2007:68). Ankara'daki 1slah imar planları da gecekondu alanlarının kentsel dönüşüm ile düzenli konutlara dönüşümü şeklinde gerçekleşmiştir. Ankara'da kentsel dönüşüm projeleri konusunda yapılan bir çalışmada ise, kentsel dönüşüm alanlarında \% 50-90 oranında nüfus değişimi yaşandığı tespit edilmiştir (Ertaş, 2011:15). 1980 sonrası Ankara'nın dönüşümünü şu cümleler ile özetlenebilir:

“1980 sonrasının Ankara'sı artık önemli değişkenlerle dönüşmekte/büyümektedir. Kent çeperlerine bloklar halinde eklemlenen konut alanlarl, marka konutlarl, eski gecekonduların yüksek katl apartmanlara dönüşen yaşam kalitesi düşük alanları, devasa alışveriş-eğlence merkezleri, sermayenin kârlı olmadı̆̆ için hiç uğramadĭ̆g yoksul-çöküntü alanları ve spekülasyona açık kentsel toprakları ile karşımızda yeni bir Ankara vardır" (Akın, 2007:261). 
Ankara'nın bu dönüşümü hızla devam etmektedir. Kentsel dönüşüm projeleri sadece TOKİ ve belediyelerin kararları ile değil, çeşitli aktörlerin katılımıyla gerçekleştirilmelidir.

"Kentsel dönüşüm projeleri, sadece Toplu Konut İdaresi ve belediyelerin tasarrufuna bırakılmadan, Ankara Dikmen Vadisi Dönüşüm Projesi'nde olduğu gibi merkezi ve yerel yönetimlerin katılımıyla birlikte akademisyenler, mühendislik ve mimarlık odaları, şehir planlamacıları, sivil toplum kuruluşları ve sosyologlardan oluşan komisyonlar tarafindan derinlemesine bir analizden sonra mevcut projeyi uygulamaya geçilmelidir" (Doğanay, 2016:103).

$\mathrm{Bu}$ şekilde gerçekleştirilen kentsel dönüşüm projeleriyle sürdürülebilir kentler oluşturulabilir. Ankara'nın kentsel dönüşüm sürecini özetlemek gerekirse;

"Ankara, Cumhuriyetin ilk döneminde kentsel toprakların kamuya kazandırllmast ve gelişimin plan yoluyla yönlendirilmesinde öncü rol oynamış; çok partili yaşama geçişle birlikte yavaş yavaş yol gösterici konumundan uzaklaşmaya, düzensiz kentsel büyümenin slkintılarıyla boğuşmaya başlamıştır; 1980'lerden sonra ise yeni liberal politikaların yerel düzeyde uygulanmasina odaklanmıştır" (Keleş ve Duru, 2008:42).

\subsection{Yenimahalle ve Kentsel Dönüşüm Süreci}

Ankara'nın Yenimahalle ilçesi, 1946-1949 yılları arasında o dönemin Ankara'nın 9'uncu Belediye Başkanı Ragıp Tüzün tarafından yapılan imar çalışmaları ile Ankara'ya yakın yerleşim alanı olarak planlanmış, 1950'li yıllarda genellikle dar gelirli işçi ve memurların konut sahibi yapılması düşünülerek kurulmuştur (Harita 2).

Harita 2. Yenimahalle Lokasyon Haritası

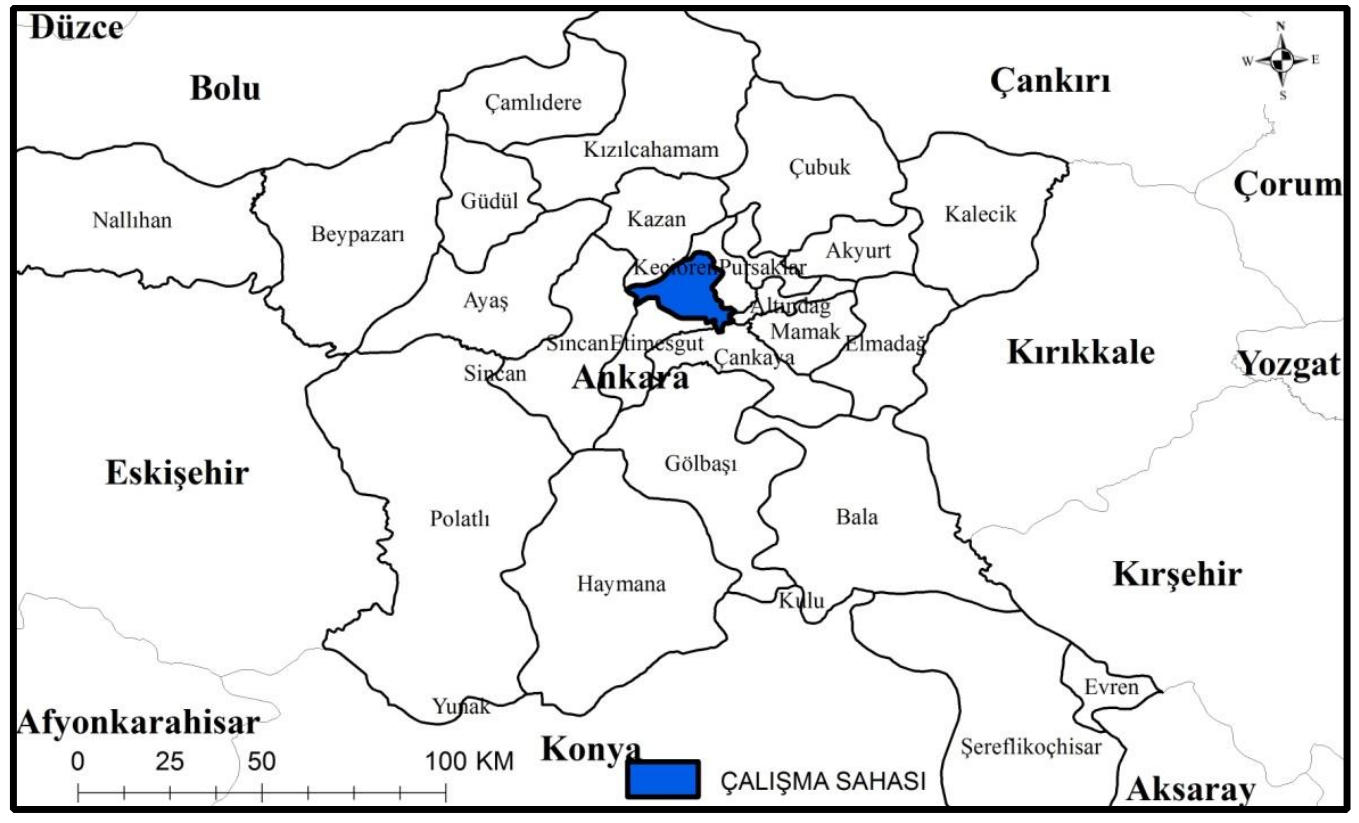

Kaynak: Yazarlar tarafından hazırlanmıştır.

Yenimahalle, 14/6/1948 tarihli ve 5218 sayıl1 "Ankara Belediyesine, Arsa ve Arazisinden Belli Bir Kısmını Mesken Yapacaklara 2490 Sayılı Kanun Hükümlerine Bağlı Olmaksızın ve Muayyen Şartlarla Tahsis ve Temlik Yetkisi Verilmesi Hakkında Kanun" kapsamında kurulan yerleşim alanıdır. Yenimahalle Belediyesi tarafindan hazineden, kooperatif ve özel kişilerden alınan arazilerin parselasyon planları yapılmıştır. Arsa tahsis edilen kişilere ise Emlâk Kredi Bankası'nca kredi sağlanmış, inşaatların büyük bir oranı üç yıl içinde tamamlanmıştır. Daha sonra ise "kamu eliyle arsa üretip konut yapacaklara devretmek" ilkesi terkedilmiş ve bu uygulama devletin konut üretimindeki rolünün tek örneği olarak olarak kalmıştır (Akın, 2007:175-176).

O dönemde hızlı bir gelişme gösteren Yenimahalle nahiyesi, 19/6/1957 tarihli ve "7033 sayılı Yeniden (78) Kaza Kurulması ve İzmir Vilayetine Bağlı Kuşadası Kazasının Aydın Vilayetine Bağlanması Hakkında Kanun" (Resmi Gazete, 1957) ile kaza veya ilçe merkezi haline getirilmiştir. 27/6/1984 tarihli ve 3030 say1lı "Büyükşsehir Belediyelerin Yönetimi Hakkında Kanun Hükmünde Kararnamenin Değiştirilerek Kabulü 
Hakkında Kanun" ile Yenimahalle İlçe Belediyesi, Çankaya, Altındağ, Mamak, Keçiören İlçe Belediyeleri ve sonrasında da Etimesgut, Sincan ve Gölbaşı İlçe Belediyeleri Ankara Büyükşehir Belediyesi'ne bağlı olarak kurulmuştur. Yenimahalle, ilçe merkezi hariç engebeli bir arazide yeralmaktadır. İlçe deniz seviyesinden 830 metre yükssekte bulunmaktadır. İlçe $274 \mathrm{~km}^{2}$ yüzölçümündedir. Türkiye İstatistik Kurumunun ADNKS 2018 verilerine göre Yenimahalle ilçesinin toplam nüfusu 663.580 kişi olup, fizyolojik yoğunluk veya kilometre kareye düşen kişi sayısı 2.421, yıllık nüfus artış \%o 6'dır (TÜiK, 2019). İlçenin Batıkent ve Yenimahalle Merkez bölgesinde orta gelir grubu aileler, Karşıyaka, Şentepe, Demetevler ve Yahyalar Mahallelerinde ise genel olarak orta ve alt-orta gelir grubuna mensup aileler yaşamaktadır. İlçe nüfusunun önemli bir bölümünü çalışan ve ücretli kesim oluşturmaktadır. Batıkent bölgesinde ise çağdaş ve modern bir yapılaşma gerçekleşmiştir. Bu bölgelerde yaşayan nüfusun önemli oranı Ankara'nın Çamlıdere ve Kızılcahamam İlçelerinden, Orta Anadolu'nun diğer illerinden ve komşu illerden gelerek yerleşmişlerdir (www.yenimahalle.gov.tr).

Yenimahalle İlçesi’nde, Yenimahalle Belediyesi Yamaçevler Kentsel Dönüşüm projesiyle bölgedeki son gecekondu alanı yerine yeni modern konutlar inşa edilecektir. Bakanlar Kurulu kararı ile bu bölgede Yukarı Yahyalar, Çiğdemtepe ve Avcılar Mahalleleri sınırları içerisindeki toplam 66 hektarlık alanda, 5.200 kişinin yaşadığı 1.300 gecekondu yıkılacak yerine yeni binalar yapılacaktır.

Yenimahalle Belediyesi çarpık kentleşmenin önlenmesi amacıyla, "Göç Ettirmeyen Kentsel Dönüşüm" sloganıyla, TOKİ ile işbirliği içerisinde Macunköy ile Pamuklar ve özel sektör ile işbirliği içerisinde Mehmet Akif Ersoy Mahalleleri Kentsel Dönüşüm Projeleri ile mevcut gecekonduların yerine ilçede sosyal donatı alanlarıyla birlikte modern konutlar oluşturmuştur (Harita 3). Genel olarak kentsel dönüşüm projesi kapsamında; Pamuklar Mahallesi'nde yıkılan gecekonduların yerine çevre düzenlemeleriyle birlikte 422 modern konut inşa edilmiş ve bu konutlardan 83'ü kura ile hak sahiplerine teslim edilmiştir. Macunköy Kentsel Dönüşüm Projesi kapsamında da, 63041 ada 2 parsel üzerine mevcut gecekondu tarz1 evlerin yerine, 1. Etap ve 2.Etap olarak toplam 683 modern konut inşa edilmiş ve projenin 1. Etabında 253 konut, 2. Etabında ise 107 konut kura ile hak sahiplerine teslim edilmiştir. Macunköy'de toplamda 360 konut hak sahiplerine teslim edilmiştir. Mehmet Akif Ersoy Mahallesi Kentsel Dönüşüm Projesi kapsamında ise, 64470 ada 4 parseldeki yıkılan 1.092 gecekondu yerine, 221 bin 13 metrekarelik alanda 22 bloktan oluşan, 3 bin 500 modern konut inşa edilmiştir. Bölgede oturan gecekondu sahiplerinden imarlı tapuları olanlara, arsanın yüzölçümüne göre 48-120 ay taksitle daire (145 metrekare alana sahip olanlara 2+1, 195 metrekare alanı olanlara 3+1, 245 metrekare alanı olana 4+1, 250 metrekare alanı olana ise 2 daire) verilmiştir. Proje kapsamında yürüyüş yolları, çocuk oyun alanları, parklar gibi sosyal donatı alanları da planlanarak yaşam alanları oluşturulmuştur. Bu kentsel dönüşüm projesi ile 4 bin aile konut sahibi olmuştur (www.yeimahalle.gov.tr).

Harita 3. Yenimahalle İlçesi Pamuklar, Macun ve Mehmet Akif Ersoy Mahalleleri

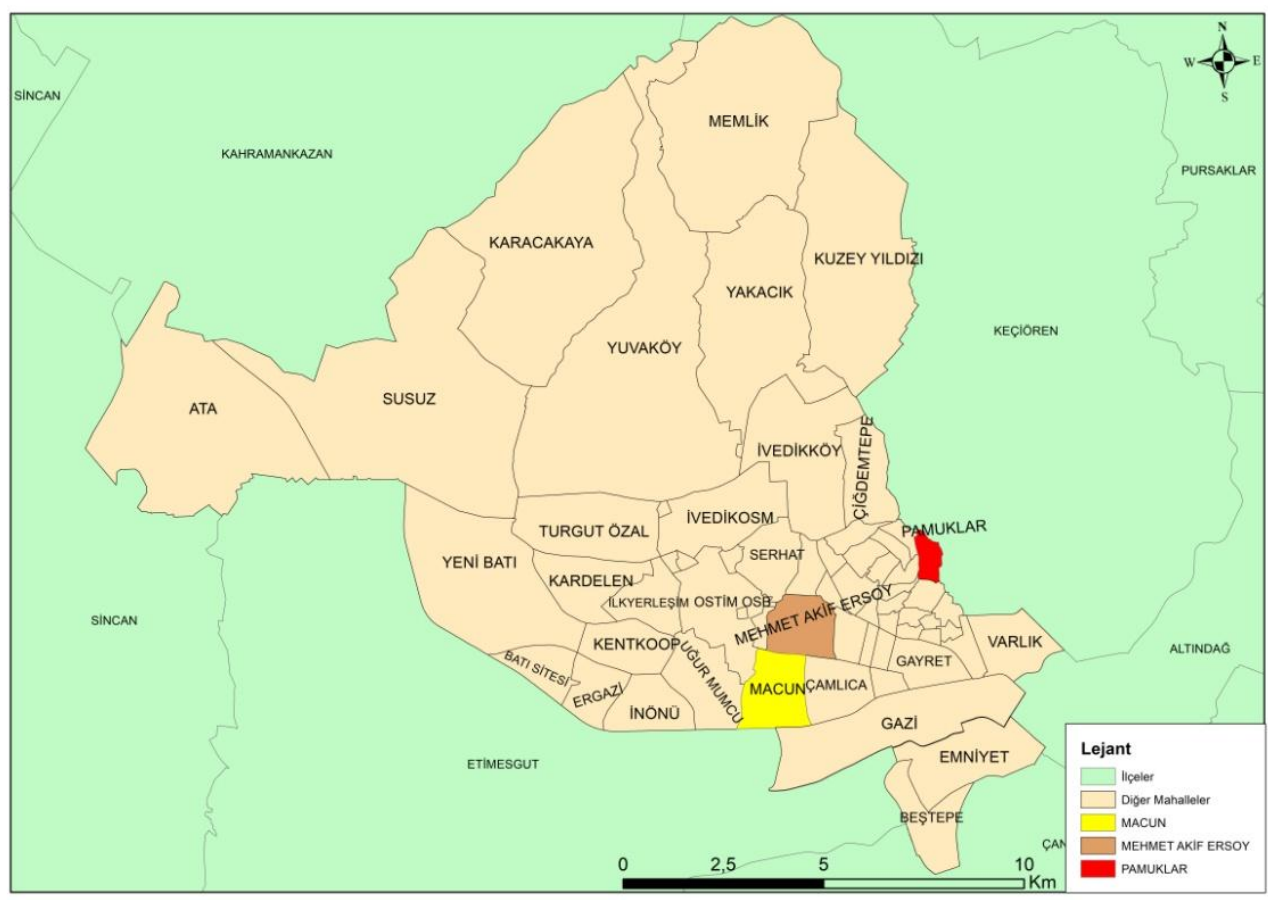

Kaynak: Yazarlar tarafından hazırlanmıştır. 
Yenimahalle Belediyesi tarafından yayınlanan broşürde söz konusu kentsel dönüşüm projeleri "İnsan Odaklı Kentsel Dönüşümler" başlığıyla tanıtılmıştır (Fotoğraf 1). Yenimahalle Belediye başkanı Fethi Yaşar; Mehmet Akif Ersoy Mahallesi kentsel dönüşüm projesinin sosyal yap1 desteğiyle Türkiye'ye örnek proje olarak göstermiştir: "Projede bölgenin ylllarca kahrın çeken gecekondu sahibi vatandaşlarımızı mağdur etmeden onların da haklarını korumayı hedefledik. Mehmet Akif Mahallesi'ndeki kentsel dönüşümün Türkiye'ye örnek olması gerekir. Bu proje kentsel dönüşüm çalışmalarında eksik olan sosyal yapıyı da sağllyor" (www.yenimahalle.bel.tr). Bu ifade de belirtildiği gibi, önceki birçok projenin aslında sosyal yap1 eksikliği bulunmaktadır. Ayrıca, Yenimahalle Belediyesi, 12-13 Mart 2016 tarihleri arasında İzmir/Seferihisar'da düzenlenen "Belediyeler Buluşması ve Yerel Yönetim Ödülleri” programında, Mehmet Akif Ersoy Kentsel Dönüşüm Projesiyle "Kentsel Gelişim" kategorisi ödülünü almıştır (www.yenimahalle.bel.tr).

Fotoğraf 1. Macunköy, Pamuklar ve Mehmet Akif Ersoy Mahallelerinde Kentsel Dönüşüm Projeleri

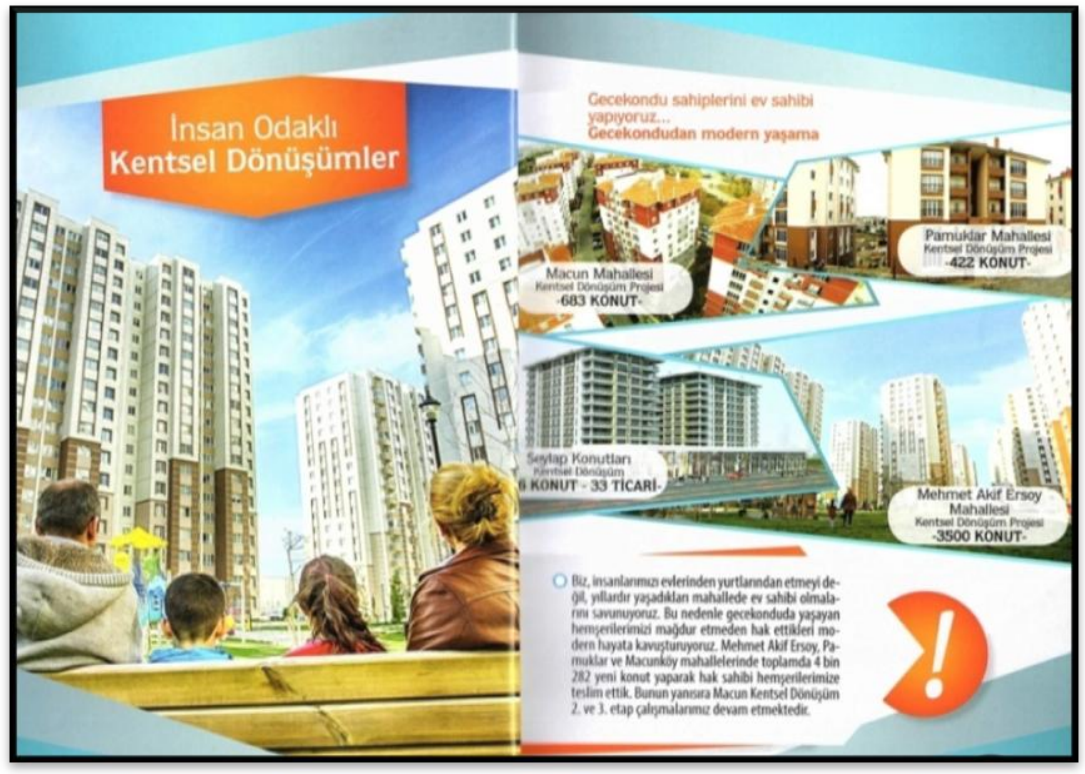

Kaynak: Yenimahalle Belediyesi Broşürü

Gecekondu dokusunun olduğu Macunköy, Pamuklar ve Mehmet Akif Ersoy Mahalleleri projeler hakkında aşağıda belirten bilgiler Yenimahalle Belediyesi raporlarından derlenmiştir. Yenimahalle İlçesi Pamuklar Mahallesi; Keçiören ilçe sınırı ile Seval Caddesi'nin kuzeyinde yer alan alanda, gecekondu yapılaşmasının bulunduğu 4 hektarlık bir alanı kapsamaktadır (Harita 3). Eskiden bu alanda 1-2 katlı, 30-40 yıllık binalarda tapu tahsis belge sahibi ve 4916 sayılı kanundan faydalanan hak sahipleri oturmaktayd1. Bu alanda kentsel yenileme veya kentsel dönüşüm projesi yürütülebilmesi amacıyla, Yenimahalle Belediyesi ile Başbakanlık Toplu Konut İdaresi Başkanlığı arasında 12/8/2009 tarihinde "Ankara-Yenimahalle-Pamuklar Kentsel Yenileme (Gecekondu Dönüşüm) Projesine İlişkin Protokol” imzalanarak süreç başlatılmıştır. 61055 ve 61056 numaralı imar adalarından oluşan bölge Toplu Konut İdaresi'nin 16/9/2009 gün ve 4567 sayılı Başkanlık Olur'u ile "Gecekondu Önleme Bölgesi” olarak ilan edilmiştir. Başbakanlık Toplu Konut İdaresince; 242 adet 3+1 daire, 180 adet $2+1$ daire olmak üzere, toplam 7 blok 422 adet daire ve çevre düzenlemeleri için, 12/2/2010 tarihinde inşaat ihalesi tarihi belirlenmiştir. Proje alanında; tapu tahsisli olan 55 kişi, tapu tahsisli olmayan 9 kişi olmak üzere toplam 64 kişiyle, 27 adet $2+1$ daire ( 52 bin TL), 52 adet $3+1$ daire olmak üzere, toplam 79 adet daire (bazı hak sahiplerine iki adet $(2+1)$ daire düşmüștür) için anlaşmalar imzalanmış ve konut alanı haricinde, ticaret ve sosyal tesis alanı da planlamaya alınmıştır (Harita 4 ve Plan 3). 
Harita 4. Yenimahalle İlçesi Pamuklar Mahallesi Kentsel Dönüşüm Alanı ve Çevresi

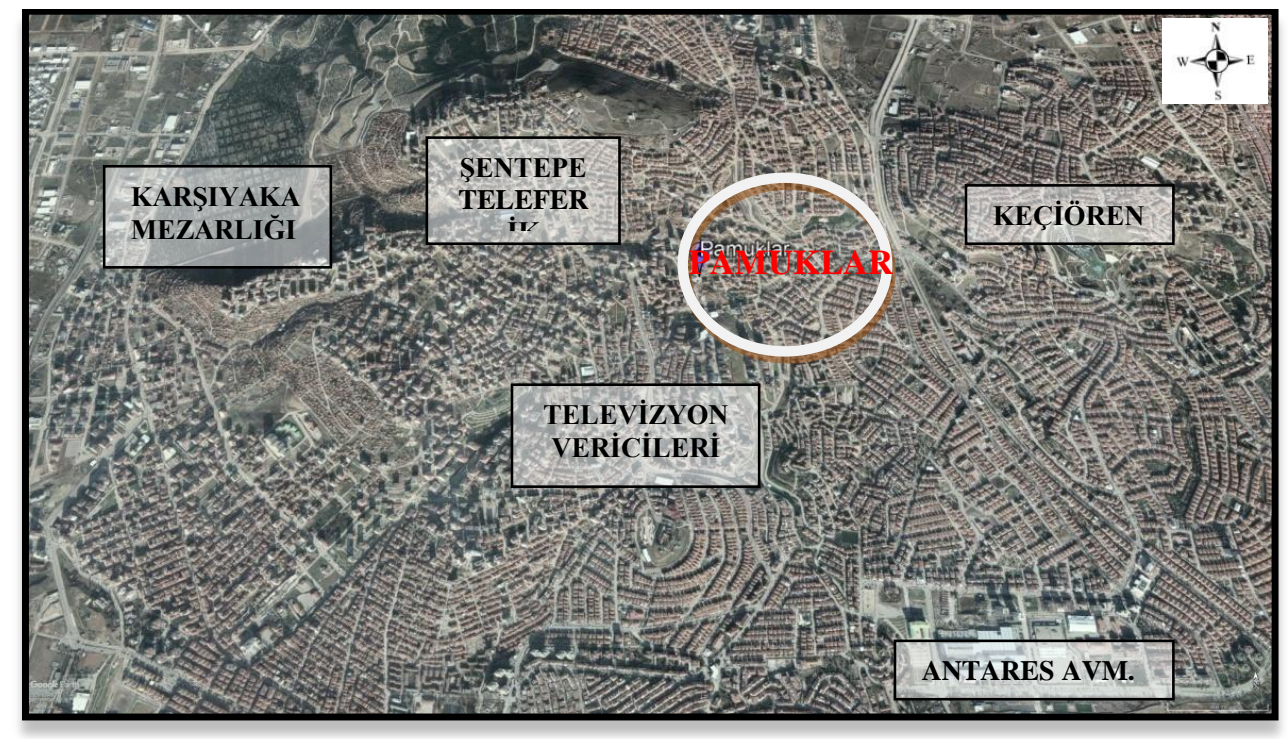

Kaynak: Google Earth Görüntüsü (2018)

Belediyenin internet sitesinde 83 olarak belirtilen daire sayısı projede 79 olarak belirtilmiş olup, aradaki fark hak sahiplerinden bazılarının belediyeye ait olan ve satılan daireleri satın almalarından kaynaklanmaktadır. Konutlarda 2012 yılından itibaren oturuma başlanmıştır (Harita 5).

Plan 3. Yenimahalle İlçesi Pamuklar Mahallesi Kentsel Dönüşüm Planı ve Haritası
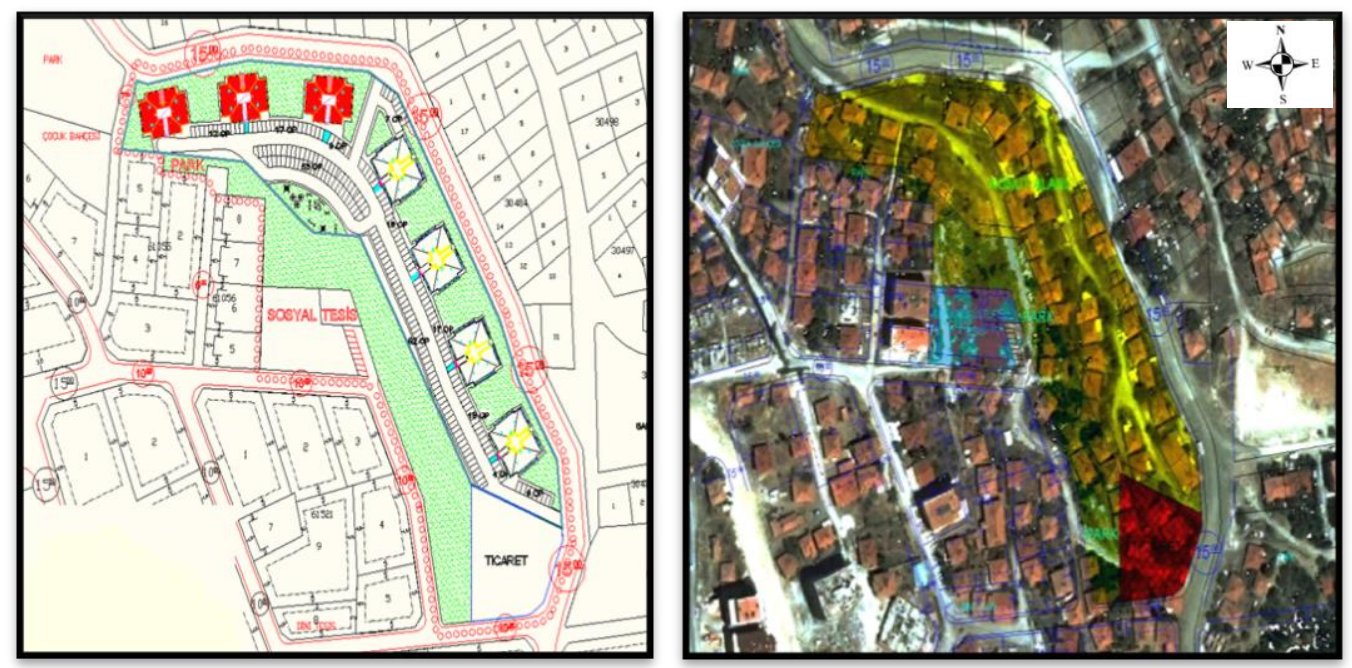

Kaynak: Yenimahalle Belediyesi Raporu

Pamuklar Mahalle Muhtarlığı ve site yönetimiyle yapılan görüşmelerde tam olarak sayısı bilinmemekle birlikte, eski gecekondu sahibinin çoğunun, yeni binalarında oturmaya devam ettiği, iki dairesi olan 15 ailenin bir kısmının ise diğer dairelerini ya kiraya verdikleri ya da sattıkları belirlenmiştir. $2+1$ evlerin 400-700 TL arası, $3+1$ evlerin ise 800-1000 TL arası kiralık olarak, $2+1$ evlerin 115-175 bin TL aras1, $3+1$ evlerin ise 160-210 bin TL arası satış fiyatlarının olması, Ankara'nın birçok semtinde yaşanan yüksek fiyatlı ev fiyatlarının bu bölgede yaşanmadığını göstermektedir. Bu konutlarda oturanlar genellikle memur kesimi oluşturmaktadır. Bu projede çevredeki mevcut gecekondu varlığı, daire sahibi eski gecekondu sahiplerinin kültürel çevreden soyutlanmadıklarından yeni konutlarında oturmaya devam etmelerine imkân sağlamaktadır. 
Harita 5. Yenimahalle İlçesi Pamuklar Mahallesi Kentsel Dönüşüm Haritası

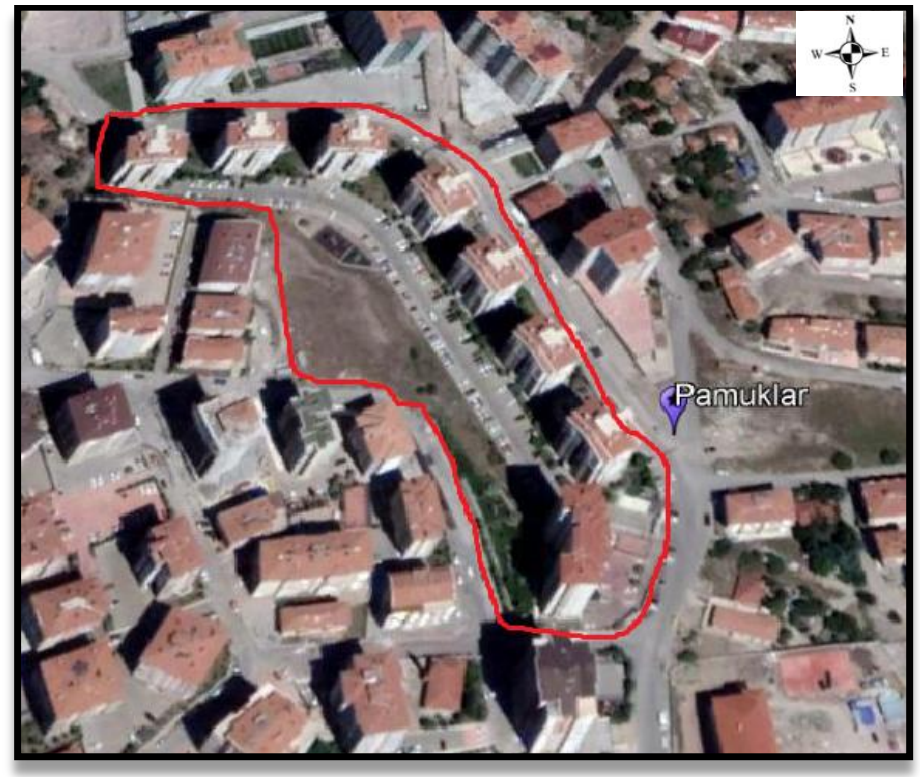

Kaynak: Google Earth Görüntüsü (2018)

Macunköy Kentsel Dönüşüm Planlama Alanı, Ankara-Yenimahalle Macun Mahallesi sınırlarındaki, yaklaşık 55 hektarlık bir alanı kapsamakta olup, köyiçi olarak anılan ve mevcut gecekondu tarzı yapılaşmanın ve köy evi tarzı 1-2 katlı, 30-40 yaşında yapıların bulunduğu, tapulu, tapu tahsis sahibi ve işgalci durumunda hak sahiplerinin bulunduğu bölgeleri kapsamaktadır (Harita 6).

Harita 6. Yenimahalle İlçesi Macun Mahallesi Kentsel Dönüşüm Alanı ve Çevresi

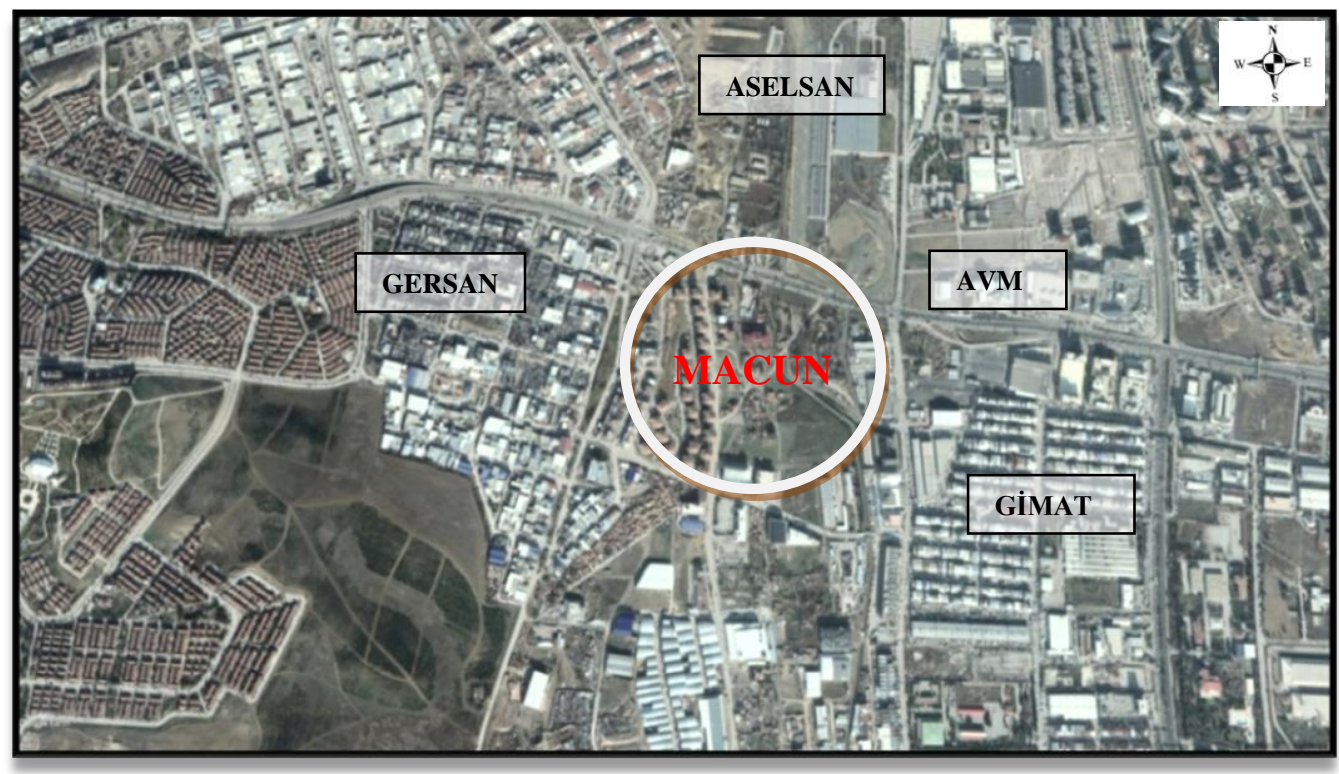

Kaynak: Google Earth Görüntüsü (2018)

Macun bölgesi ile ilgili olarak mer'i imar planları Yenimahalle Belediye Meclisi'nin 1/5/1992 gün ve 61 sayılı Ankara Büyükşehir Belediye Başkanlığı'nın 16/10/1992 gün ve 2032/92 sayılı yazıları ile onaylanmıştır. Proje alanı Toplu Konut İdaresi'nin 25/9/2008 tarihli ve 4629 sayılı Başkanlık Olur'u ile "Gecekondu Önleme Bölgesi”" olarak ilan edilmiştir. Proje alanı kapsamı, ilave olarak, Macun 2. Bölge ile genişletilerek Toplu Konut 
İdaresi’nin 12/8/2009 tarihli ve 3948 sayılı Başkanlık Olur'u ile “Gecekondu Önleme Bölgesi” olarak ilan edilmiştir (Plan 4).

Plan 4. Yenimahalle İlçesi Macun Mahallesi Kentsel Dönüşüm 1. ve 2. Bölge İmar Planları
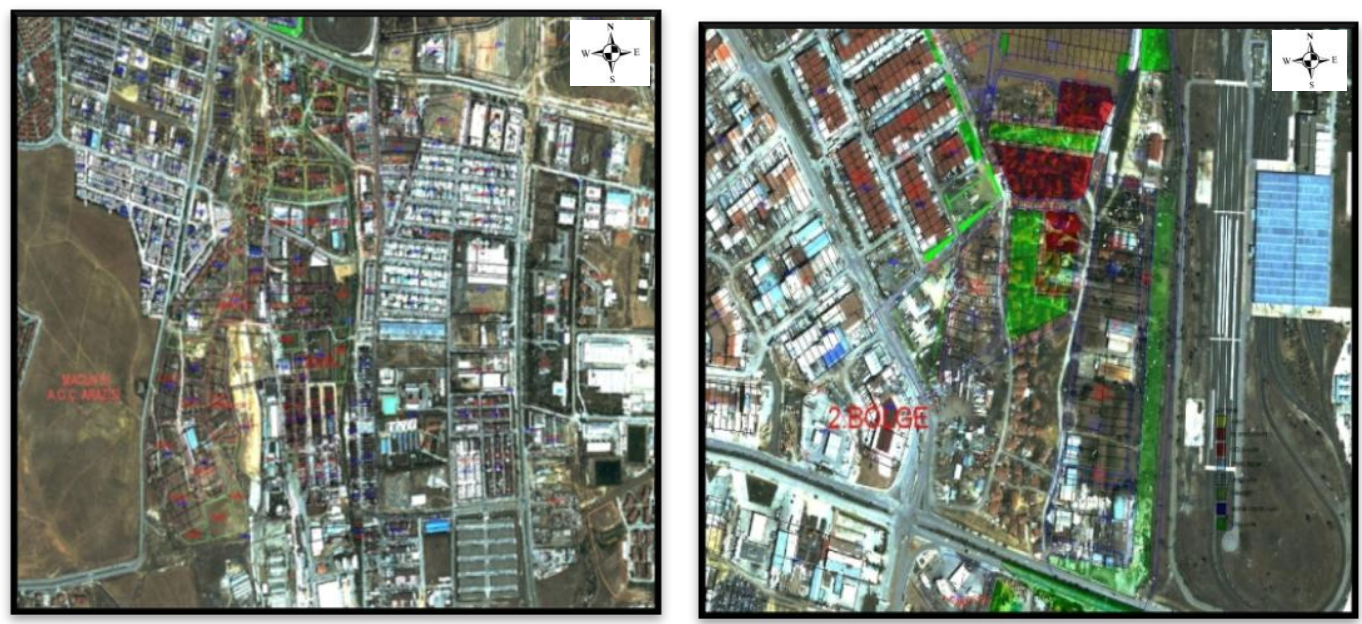

Kaynak: Yenimahalle Belediyesi Raporu

Gecekondu Kanununun 19. Maddesi ve Uygulama Yönetmeliği’nin 59. Maddesi kapsamında onaylanan 1/5000 ölçekli “Ankara-Yenimahalle-Macun Mahallesi Gecekondu Önleme Bölgesi Nazım İmar Planı Değişikliği” ile 1/1000 ölçekli "Ankara-Yenimahalle-Macun Mahallesi Gecekondu Önleme Bölgesi Uygulama İmar Planı Değişikliği”, 18/8/2009 günlü Resmi Gazetede yayınlanmıştır. Onaylı imar planları doğrultusunda hazırlanan parselasyon planları Toplu Konut İdaresi'nin 8/10/2008 tarihli ve 4896 sayılı Başkanlık Olur'u ile onaylanarak askıya çıkarılmış, ilan süresini itirazsız olarak askıdan indirilerek onaylanmıştır. Yenimahalle belediyesi TOKİ ile 1/7/2008 tarihinde imzalanan protokol ile kentsel yenileme alanında ikamet eden tapu sahibi olan veya olmayan vatandaşlardan mülkiyetlerinde bulunan arsa, bina ve eklentilerini, aynı alanda yapılacak konutlardan yapılardan mahsuplaşma veya borçlandırma yoluyla konut edinmelerini sağlamıştır. Macunköy Kentsel Dönüşüm Projesi kapsamında da 63041 ada 2 parsel üzerine mevcut gecekondu tarzı evlerin yerine, 1. Etap ve 2. Etap olarak toplam 683 modern konut, 2012 ve 2013 yıllarında inşa edilmiştir (Plan 5, Fotoğraf 2).

Plan 5. Yenimahalle İlçesi Macunköy Kentsel Dönüşüm 1. Bölge İmar Planı ve Haritası
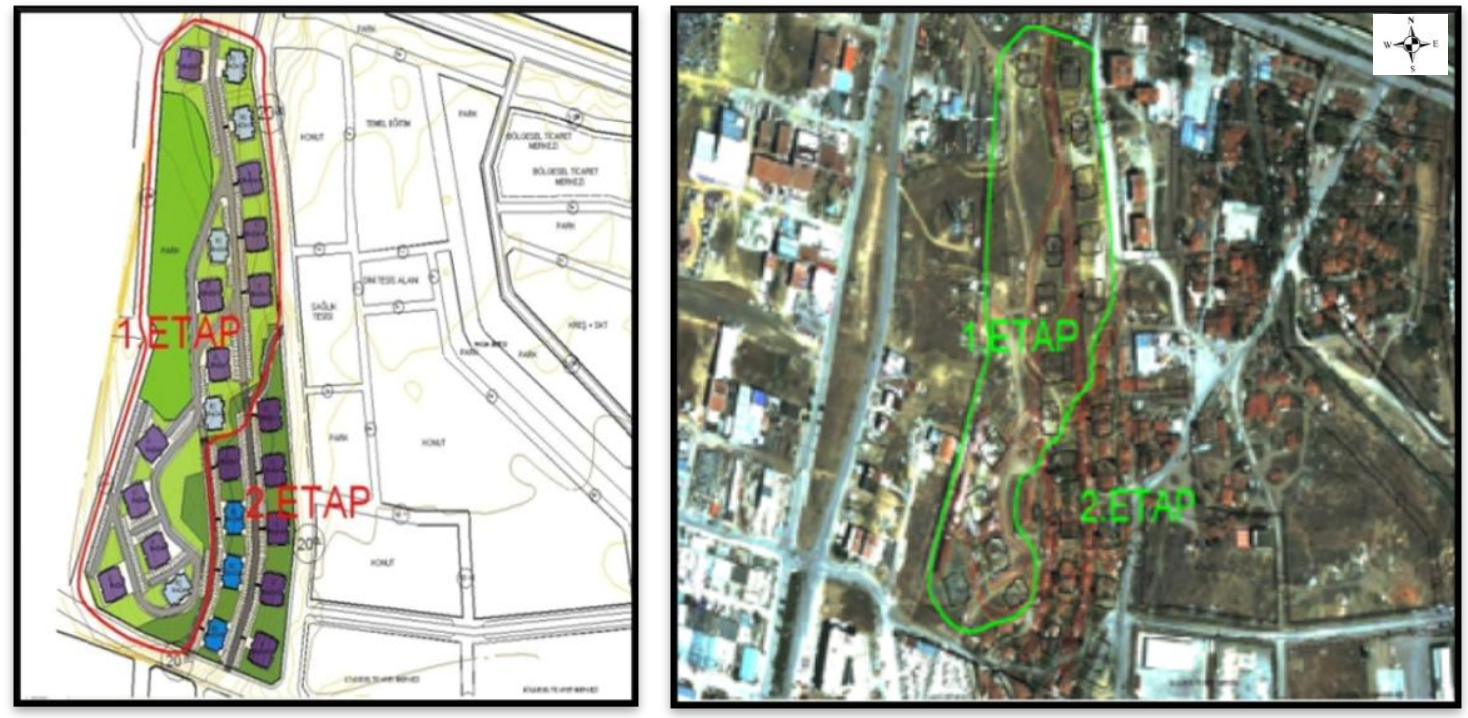

Kaynak: Yenimahalle Belediyesi Raporu

Yenimahalle Belediyesi raporlarında proje alanı kapsamında; 2981 sayılı İmar Affı Kanunundan faydalanan 281 hak sahibi ve 775 sayılı Gecekondu Kanunundan faydalanan 114 hak sahibi olmak üzere toplamda 395 hak sahibi bulunduğu belirtilmiş olmakla birlikte, belediyenin internet sitesinde projenin 1.Etabında 253 konut, 2.Etabında ise 107 konut olmak üzere toplamda 360 konutun kura ile hak sahiplerine teslim edildiği 
belirtilmektedir. $\mathrm{Bu}$ farkın, raporda belirtilen hak sahiplerinin bir kısmının konut almayı tercih etmemesi veya mahkeme süreçlerinin devam etmesi nedeniyle konut alamadıklarından kaynaklandığı değerlendirilmektedir.

Fotoğraf 2. Yenimahalle İlçesi Macun Mahallesi 2009 ve 2018 yılı Kentsel Dönüşüm Alanı
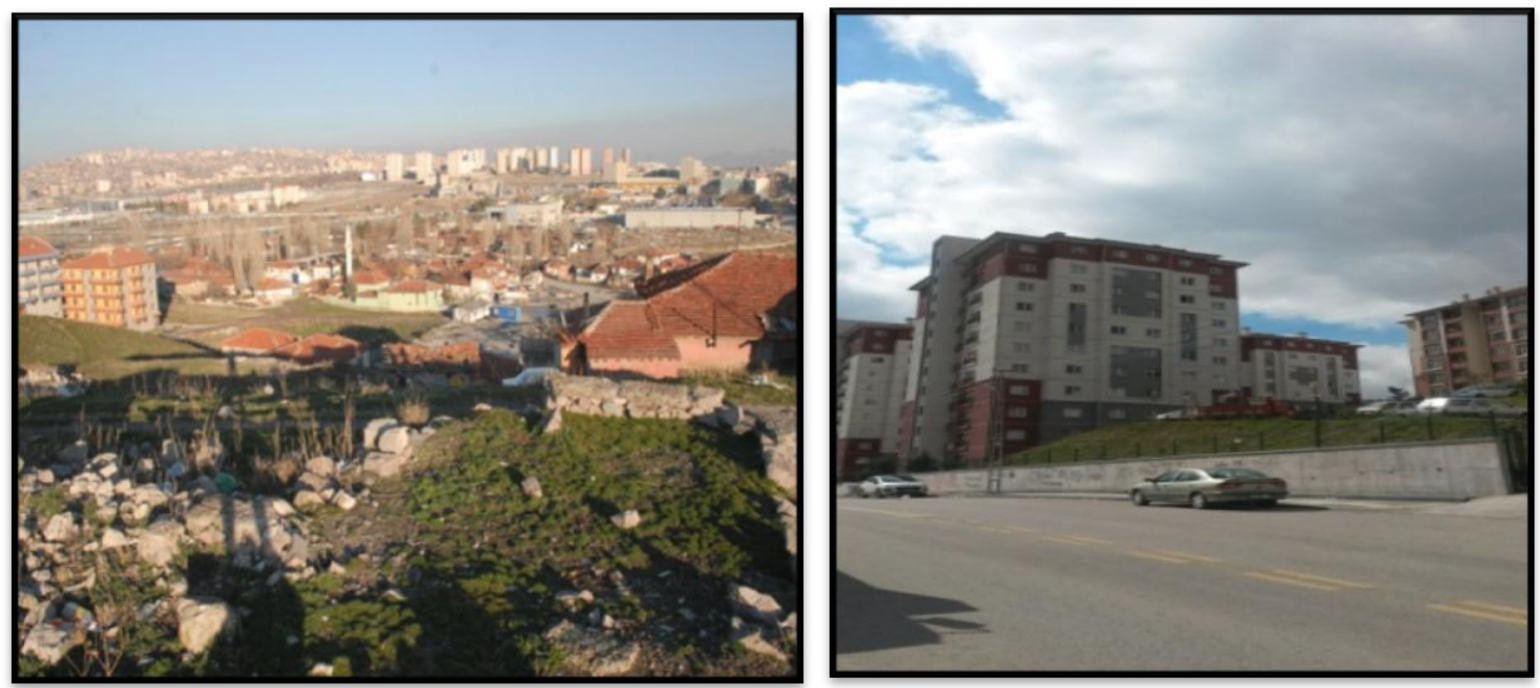

Kaynak: Yazarların Arşivinden

Macunköy Kentsel Dönüşüm Projesi kapsamında da 1. Bölge, 3. Etap çalışmalarına henüz başlanmamış olup, $\mathrm{Bu}$ alana Aselsan ilkokulunun yapıldığı ve yakın zamanda modern konutların inşa edileceği, bu alan üzerindeki konut veya arsa sahiplerinden yaklaşık 100'üne yeni yapılacak konutların kura ile teslim edileceği Macun Mahallesi Muhtarıyla yapılan görüşmede öğrenilmiştir. Ayrıca; Macunköy Kentsel Dönüşüm Projesi 1. Bölge, 1. ve 2. Etaptaki eski gecekondu sahiplerinden yaklaşık \% 90'ının yeni binalarında oturmaya devam ettiği, iki dairesi olan ailelerin bir kısmının ise diğer dairelerini ya kiraya verdikleri ya da sattıkları anlaşı1mıştır.

Mehmet Akif Ersoy Kentsel Dönüşüm Alanının güneyinde GiMAT Toptancılar Sitesi ve Büyük bir AVM ve Urankent Sitesi, batısında Macunköy Metro istasyonu ve ASELSAN, doğu kısmında ise Dr. Abdurrahman Yurtaslan Ankara Onkoloji Eğitim ve Araştırma Hastanesi ve kuzeyinde ise henüz yapılaşmamış Kentsel Çalıșma Alanlarıyla konumlanmıș bir alanda yer almaktadır. Mehmet Akif Ersoy Kentsel Dönüșüm Alanının orta kısmından 35 metre genişliğinde Anadolu Bulvarı geçmekte ve yaklaşı 200 metre kuzeyinde Mehmet Akif Ersoy Caddesi bulunmaktadır. Alanın kuzey kısmı 324. Sokak, kuzeydoğu kısmı ise Vatan Caddesi ile güney kısmı ise 283. Cadde (eski 14.Cadde) ile sınırlanmaktadır. Alanın batı kısmı 295. Sokak (eski 63. Sokak) doğu kısmı ise 313. Sokak (eski 84. Sokak) ile sınırlanmıştır. Söz konusu Alanın 550 metre güneyinde Anadolu Bulvarı üzerinde bulunan GIMAT Alt Geçidi (GIMAT Kavşağı) bulunmaktadır (Harita 7).

Harita 7. Mehmet Akif Ersoy Kentsel Dönüşüm Alanı ve Çevresi

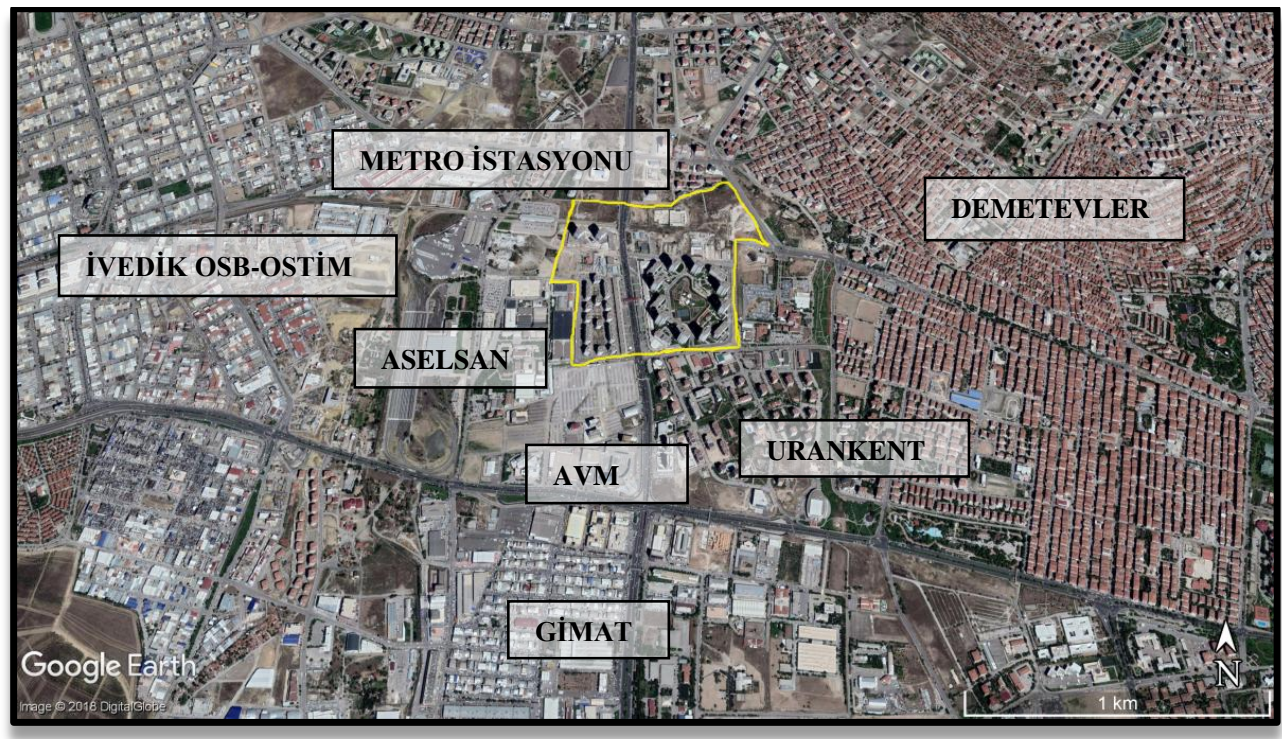

Kaynak: Google Earth Görüntüsü (2018) 
Islah İmar Planı ile ilk kentsel dönüşüm projesi kapsamında; Mehmet Akif Ersoy Mahallesi güneyini kapsayan 1/1000 ölçekli Islah İmar Planı, Yenimahalle Belediye Meclisi'nin 2/2/1994 gün ve 23 sayılı kararı ile onaylanmıştır. 1/1000 ölçekli Islah İmar Planı'nın uygulaması, yani parselasyon planı yapılmış, ancak Islah İmar Planı'nın uygulanmasına başlanmadan, Yenimahalle Belediyesi'nce kentsel dönüşüm uygulamasının yapılması için Ankara Büyükşehir Belediyesi'ne başvurulmuştur. Ankara Büyükşehir Belediye Meclisi'nin 14/12/2001 gün ve 689 sayılı kararı ile 1/5000 ölçekli Mehmet Akif Ersoy Mahallesi Kentsel Dönüşüm Projesi Nazım İmar Planı onaylanmış, plan doğrultusunda hazırlanan 1/1000 ölçekli Islah İmar Planı Yenimahalle Belediye Meclisi'nin 5/2/2004 gün ve 40 sayılı kararı ile onaylanmıştır.

Söz konusu Kentsel Dönüşüm Projesi kapsamında yürürlükteki onaylı imar planları ile mevcut sslah imar planı yoğunluk kararları aynı şekilde korunarak yeni donatı alanları öngörülmüş, ulaşım kararları yeniden tasarlanmıştır. Kamu yararı ve şehircilik ilkeleri gözetilerek daha sağlıklı ve yaşanabilir, aynı zamanda prestijli bir çekim alanı oluşturulması hedeflenerek, artırılan donatı alanları ile diğer bölgelere de hizmet verecek yaşam alanları oluşturulması öngörülerek plan tadilatı yapılmıştır. Mehmet Akif Ersoy Mahallesi Kentsel Dönüşüm Projesi; imar tapulu arsa sahiplerini, imar tapulu arsası üzerinde yapısı bulunan gayrimenkul sahiplerini, 2981 sayılı yasaya tabi tapu tahsis belgeli gecekondu hak sahiplerini ve tapu veya tapu tahsis müracaatı bulunmayan hak sahibi olmayan/olamayan durumundaki gecekondu sahiplerini kapsamıştır.

Kentsel Dönüşüm Alanında 5393, 2981, 3194, 775 ve 2942 sayılı yasa ile değişik 4650 sayılı yasalar çerçevesinde mevcut çarpık yerleşme alanlarının tasfiye edilerek, çağdaş özelliklere sahip modern standartlarda yeni bir yerleşim alanı oluşturulması hedeflenmiş; eğitim (anaokulu kreş ve ilköğretim), cami, spor, ticaret ve alışveriş merkezi, çocuk parkı, yol ve otopark gibi sosyal ve teknik altyapı alanlarının yanı sıra konut düzenlemelerini de içeren söz konusu proje kapsamında, ilgili mevzuat doğrultusunda Belediye Meclisleri ve Encümenlerince sınır ilanı, imar planları (1/5000 ve 1/1000) ve parselasyon planları onaylanmış ve planının tapuda tescili ile birlikte inşaat uygulaması sürecine başlanmıştır (Plan 6).

5393 sayılı Belediye Kanunu ve ilgili hükümleri doğrultusunda 3.600 konuttan oluşan ve bu konutlarda yaşayacak yaklaşık 14400 kişi düşünülerek (alanda yaklaşık 1.030 adet gecekondu mevcuttu) Mehmet Akif Ersoy Mahallesi Kentsel Dönüşüm ve Gelişim Projesi Alanına ilişkin 1/1000 ölçekli Uygulama İmar Planı, Yenimahalle Belediye Meclisi'nin 7/5/2007 gün ve 301 sayılı kararı ile uygun görülerek Ankara Büyükșehir Belediyesi Meclisi’nin 18/5/2007 tarihli ve 1363 sayılı kararı ile 1/5000 ölçekli Nazım İmar Planı ile birlikte onaylanarak askı sürecini de itirazsız tamamlamış, Mehmet Akif Ersoy Mahallesi Kentsel Dönüşüm ve Gelişim Proje Alan Sınırı 1/6/2007 tarih ve 26539 sayılı Resmi Gazetede ilan edilerek kesinleşmiştir. Mevcutta, planlama alanı bütününde toplam 3.600 konut öneriliyorken, yaşayacak olan toplam nüfus da 14.400 kişi (3.600x4) olarak öngörülmüştür. Öneri planında toplamda 3.700 konut görülürken, yaşayacak olan toplam nüfusun da 12.691 kişi $(3.700 \times 3,43)$ olması öngörülmüştür. Mevcut planın onaylandığ zamanda ortalama hane halkı büyüklüğü 4 olarak alınmıştır. Adrese Dayalı Nüfus Kayıt Sistemine (ADNKS) göre 2009 yılı Yenimahalle ilçesi için verilen ortalama hane halkı sayısı ise 3,43 olarak belirlenmiştir. Bu sayıya göre önerilen nüfus ile (mevcut plana göre nüfus 14.400 iken, öneriye göre nüfus 12.691) donatı alanlarının büyüklügü dengelenmiştir.

Plan 6. Mehmet Akif Ersoy Kentsel Dönüşüm Planı

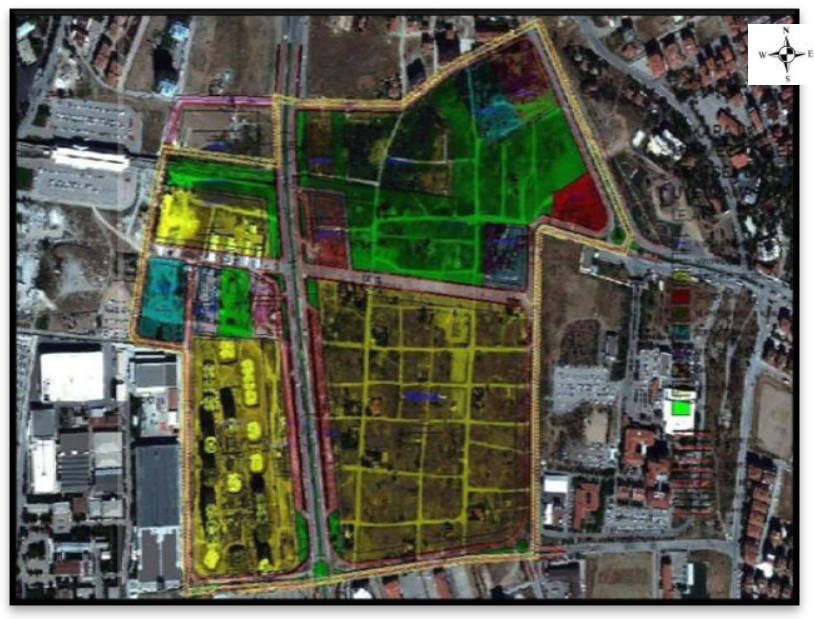

Kaynak: Yenimahalle Belediyesi Raporu 
Mehmet Akif Ersoy Mahallesi'nde yer alan gecekondu sahipleri ve hak sahiplerine haklarına düşen 1.502 adet konut yapılmak üzere 62068 ada 1 parsel ihale ile özel şirkete verilmiş ve ihale koşullarına göre 62068 ada 1 parselde yapılacak 1.502 konutun inşaat aşamaları oranında 62069 ada 1 parselin tamamı $\left(140.699 \mathrm{~m}^{2}\right), 62068$ ada 1 parselin $12.095 \mathrm{~m}^{2}$ 'si ve $16.811 \mathrm{~m}^{2}$ 'si 62068 ada 1 parselin doğu kısmı (Anadolu Bulvarı cephesinde) olmak üzere toplam $169.605 \mathrm{~m}^{2}$ 'sinin ilgili şirketin mülkiyetine geçecek şekilde anlaşma sağlanmıştır. Söz konusu Mehmet Akif Ersoy Kentsel Dönüşüm alanında yaşanan değişim süreci 2003 ve 2018 yılı uydu görüntüleriyle (Harita 8,9) daha iyi görülmektedir.

Harita 8. Mehmet Akif Ersoy Kentsel Dönüşüm Alanı (2003)

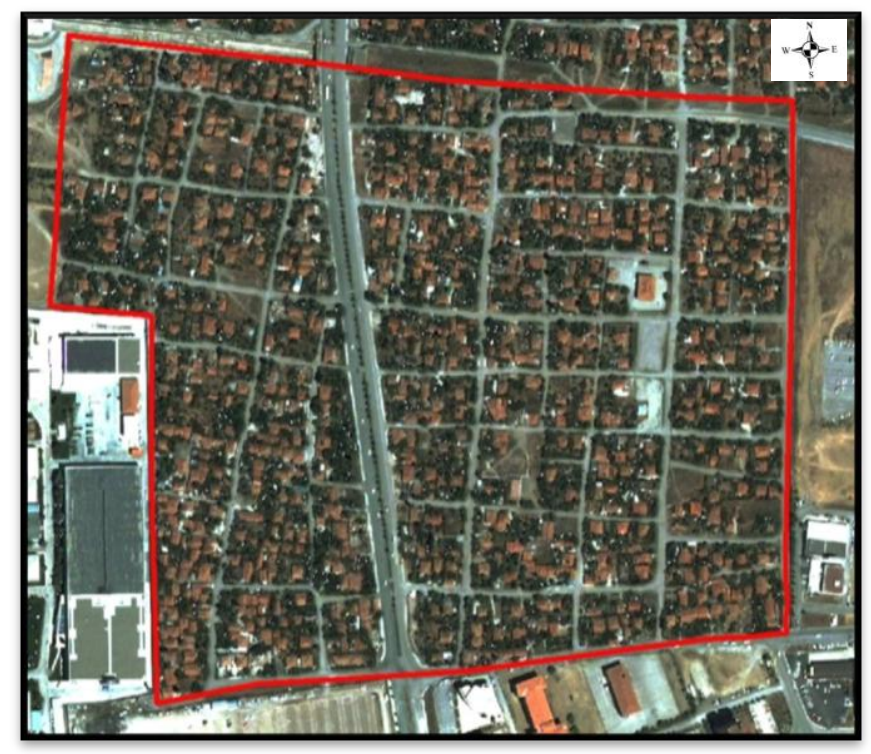

Kaynak: Google Earth Görüntüsü (2003)

Harita 9. Mehmet Akif Ersoy Kentsel Dönüşüm Alanı (2018)

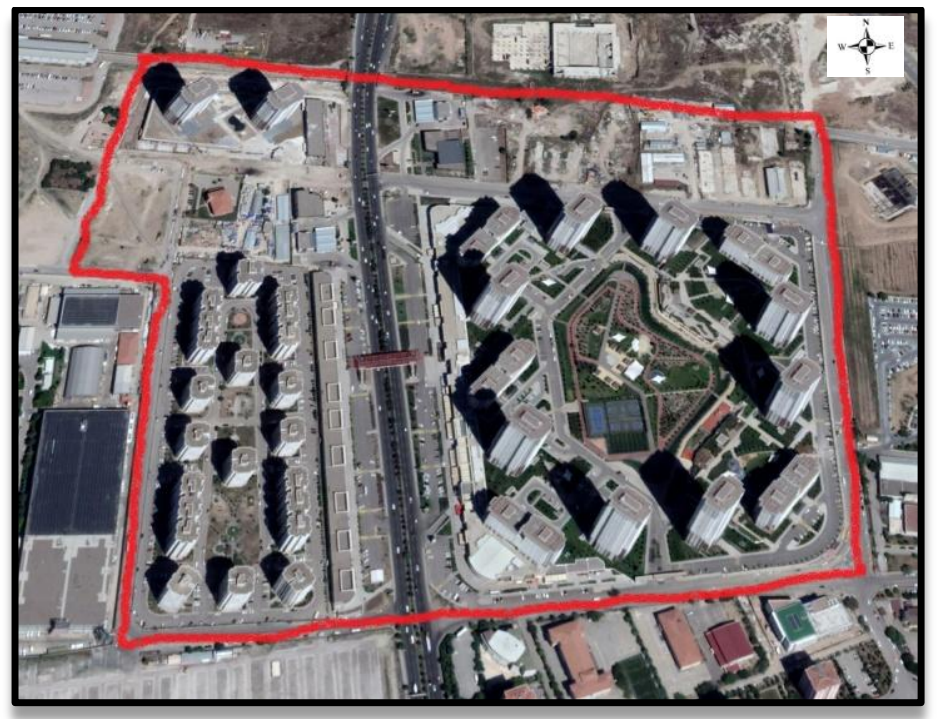

Kaynak: Google Earth Görüntüsü (2018)

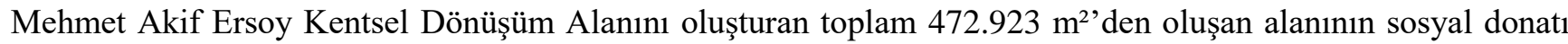
alanları bakımından; Anadolu Bulvarı doğusu ve batısında yer alan temel eğitim alanı, kreş alanı, ticaret, bakım akaryakıt istasyonu, parklar ile dini tesis alanı ve spor alanı kullanımları bakımından özellikle eski gecekondu sahiplerinin oturduğu Anadolu Bulvarı batısı önemli yer tutmaktadır (Tablo 1). 
Tablo 1. Mehmet Akif Ersoy Kentsel Dönüşüm Kullanım Alanları

\begin{tabular}{|c|c|c|}
\hline Kullanım Alanları & Batısı $\left(m^{2}\right)$ & Doğusu $\left(\mathbf{m}^{2}\right)$ \\
\hline Park & 69.662 & 19.140 \\
\hline Kreş & 7.651 & 4.874 \\
\hline Temel Eğitim & 9.067 & 9.206 \\
\hline Konut-Kentsel Servis & 137.378 & 79.224 \\
\hline Bakım Akaryakıt İstasyonu & 6.298 & 4.038 \\
\hline Spor & 23.073 & - \\
\hline Dini Tesis & 9.047 & - \\
\hline Ticaret & 5.571 & - \\
\hline Refüj & \multicolumn{2}{|c|}{3.559} \\
\hline Yollar & \multicolumn{2}{|c|}{85.135} \\
\hline Toplam & \multicolumn{2}{|c|}{472.923} \\
\hline
\end{tabular}

Kaynak: Yenimahalle Belediyesi Raporlarından Derlenmiştir.

Mehmet Akif Ersoy Kentsel Dönüşüm süreci 2014 yılında tamamlanarak, mesken sahiplerince oturulmaya başlanmıştır. Mehmet Akif Ersoy Kentsel Dönüşüm Alanındaki 62068 ada 1 parselde yapılan 1502 konuttan Harita 8'de görülen 1.030 gecekondu sahiplerinden imarlı tapuları olanlar, arsanın yüzölçümüne göre 48-120 ay taksitle daire sahibi olmuştur. Yenimahalle Belediyesi yetkilileri yapılan mülakatta tam olarak sayısı bilinmemekle birlikte 1.030 eski gecekondu sahibinin yaklaşı 700 'ünün yeni konutlarında oturmaya devam ettiği, diğerlerinin ise ya konutlarını satarak ya da kiraya vererek taşındıkları anlaşılmıştır.

Mehmet Akif Ersoy Mahalle Muhtarlığ1 ve site yönetimi ile yapılan mülakatlarda, 60-70 kadar gecekondu sahibinin, oturduğunu kanıtlayacak herhangi bir belge (elektrik, su faturası, oy kullandığına dair belge vb.) ibraz edemediğinden dolayı konut sahibi olamadığı anlaşılmıştır. Bu durum belediyenin internet sitesi ile raporlarında da görülmektedir (belediyenin internet sitesinde 1.092 gecekondu sahibi denilirken yukarıda belirtilen raporda ise 1.030 gecekondu sahibi olarak belirtilmektedir). Ayrıca \% 70-80 oranındaki gecekondu sahibinin yeni konutlarında oturmaya devam ettiği belirtilmiştir. Taşınan eski gecekondu sahibinin ise daha çok Etimesgut veya Sincan gibi Ankara'nın yakın ilçelerini tercih ettikleri belirtilmiş olup, bunda ise eski alışık oldukları sosyo-ekonomik koşullarda yaşama imkânına sahip olmayı tercih etmelerinin önemli bir etkisinin olduğu değerlendirilmektedir. Bununla birlikte, 2+1 konut sahibinin bazıları da evin küçük, balkon ve ayrı bir tuvaletin olmaması gibi mimari özellikler ve çocuk sayısının fazla olması nedeniyle daha büyük $(3+1$ veya $4+1)$ ama yaklaşık aynı fiyatta olan daha uygun fiyatta evlerin bulunduğu yakın bir eve taşınmayı tercih ettikleri görülmüştür. Başka bir ilçe veya mahalleye taşınan eski gecekondu sahibinin daha çok evini satmak yerine, evini kiraya verdikleri tespit edilmiştir. Evlerin kiralık değerinin emlakçılar ile yapılan görüşmelerde, evlerin zamanla değer kazandığı (kiralık $2+1$ evler 900-950 TL) tespit edilmiştir. Evini satanların ise özellikle de 2+1 evlerinin değer kazanması (satılık 2+1 evler 220-230 bin TL) nedeniyle evlerini satmışlardır. Sitede oturan birkaç aile reisi ile çeşitli vesilelerle yaptığım mülakatta evlerinin avantajlı bir konumunun olduğunu, 15 dakika içerisinde istedikleri yere gidebildiklerini, alışveriş merkezi, metro durağı gibi yerlerin yakınında oturduklarını beyan etmişlerdir. 
Mehmet Akif Ersoy Kentsel Dönüşüm Projesi'nde oturmaya devam eden eski gecekondu sahibinin yaklaşı \% 70-80'ler oranında olması, bu projenin daha önceki kentsel dönüşüm projelerinden farklılığını göstermektedir. Bu bölgede oturan özellikle İç Anadolu Bölgesi illerinden (Yozgat, Çorum, Çankırı, Gümüşhane vb.) 30-40 yıl önce iç göçle gelen eski gecekondu sahipleri ile aile bireylerinin bir kısmının Macunköy Kentsel Dönüşüm Projesinde olduğu gibi yakın çevrede bulunan sanayi bölgelerinde çalışmaları nedeniyle bu bölgede yaşamayı tercih ettikleri veya yaşamaya devam etmelerini gerektiren ekonomik şartların olduğu değerlendirildiğinde bu farklılık daha iyi anlaşılmaktadır.

\section{SONUÇ}

Kentsel dönüşüm projeleri; hızlı kentleşmenin etkisiyle oluşan sağlıksız ve niteliksiz alanların yeniden dönüşümü maksadıyla gerçekleştirilmektedir. Kentsel dönüşümün hedefinde kentlerin hayat standartlarını geliştirmek yer almaktadır. Kent merkezlerindeki gecekondulaşma ve çarpık yapılaşma nedeniyle bozulan kent alanları, kentsel dönüşüm projeleriyle yeniden kente kazandırılmaktadır.

Türkiye'de kentsel dönüşüm projelerinde; fiziksel dönüşümün yanında, sosyal ve ekonomik dönüşümün de sağlanması amaçlanmış olmasına rağmen, gerçekleştirilen projelerde sadece fiziksel dönüşüme yönelinmiş, sosyal ve ekonomik dönüşüm göz ardı edilmiştir. Eski yerleşimcilerin kentle bütünleşme süreci amacına ulaşamamıştır.

Ankara'da, Türkiye'de de görüldüğü gibi, öncesinde gecekonduların bulunduğu bölgelerin yerini, kentsel dönüşüm projeleri ile nitelikli yüksek katlı apartmanlar almış, fiziksel dönüşümün yaşanmasına, arsa ve konut fiyatlarının yükselmesine neden olmuştur. Bu bölgede eskiden oturan gecekondu sahiplerinin; kültürel yapı farklılıkları, alt gelir grubunu oluşturmaları nedeniyle, kendilerine verilen evlerini satmasına veya kiralık başka bir bölgeye gitmelerine neden olmuştur.

Yenimahalle Belediyesi’nin “Göç Ettirmeyen Kentsel Dönüşüm” sloganıyla başlattığı TOKİ ile işbirliği içerisinde Macunköy, Pamuklar ve özel sektörle işbirliği içerisinde Mehmet Akif Ersoy Mahallelerinde Kentsel Dönüşüm Projeleri ile mevcut gecekonduların yerine ilçede sosyal donatı alanlarının bulunduğu modern konutlar oluşturulmuştur. Macunköy, Pamuklar ve Mehmet Akif Ersoy Mahallelerinde oturmaya devam eden eski gecekondu sahiplerinin oranının yaklaşık \% 70-90'larda olması, bu projelerin Ankara'da ve ülke genelinde daha önceki kentsel dönüşüm projelerinden farklılığını göstermektedir. Bu bölgeden özellikle Mehmet Akif Ersoy Mahallesi kentsel dönüşüm projesi alanının alışveriş merkezlerine ve metro istasyonuna yakınlığı, ana karteller üzerinde olması ve ulaşım kolaylığı gibi nedenlerle konut fiyatlarının yükselmesine yol açmış, yakın zamanda mimari özelliklerinin olumsuz etkisi ile bazı konut sahiplerinin evlerini satarak veya kiraya vererek başka bölgelere gidebilecekleri değerlendirilmektedir. Özetle belediyelerin "Göç Ettirmeyen Kentsel Dönüşüm" sloganıyla gerçekleştirdikleri projelerden biri olan ve üzerinde çalış1lan kentsel dönüşüm alanlarındaki nüfusun ekonomik ve sosyal yapısının zamanla değişimi beklenen bir sonuç olacaktır.

11/5/2018 tarihli Kanun ile 3194 sayılı İmar Kanununa geçici madde eklenmesiyle yeni imar affı kanunu yasalaşmıştır. Söz konusu geçici madde ile 31 Aralık 2017 tarihinden önce yapılmış yapılara kentsel dönüşüm uygulamasına veya yapının yeniden yapılmasına kadar geçerli olan "Yap1 Kayıt Belgesi" verilecek olup, önümüzdeki yıllarda çok sayıda eski, çarpık veya gecekondu alanları kentsel dönüşüme uğrayacaktır. Bu süreçte uygulanacak kentsel dönüşümler; sosyal gelişim, ekonomik kalkınma, çevreyi koruma faktörleri göz önünde bulundurularak, bütüncül bir yaklaşımla gerçekleştirilmelidir. Uygulanacak planlamalarda; coğrafyacı, sanat tarihçi, sosyolog, psikolog, hukukçu, şehir plancısı, mimar, mühendis gibi farklı disiplinlerden oluşan mesleklerden oluşan bireylerin multidisipliner şekilde çalışmalarına önem verilmeli, çevresel ve fiziksel iyileştirme dışında, dikey yapılaşma yerine yatay yapılaşmaya önem verilmeli, toplumun temel ihtiyacı olan sosyal donatılar, sağlık birimleri ve çeşitli kültürel etkinlikler, halkın yeteneklerini geliştirebileceği sosyal etkinlikler mutlaka kentsel dönüşüm projelerinde yer almalıdır. Kentsel dönüşüm projelerinin sürdürülebilirliği açısından; özel sektör, sivil toplum ve yerel halk sürece dâhil edilmelidir. Eğer tüm bunlar sağlanamazsa tüm kentsel dönüşüm projeleri ve yatırımlar; sağlıksız kentsel gelişime neden olacak, böylece israf ve kentsel yağma kaçınılmaz olacaktır. 


\section{KAYNAKLAR}

AÇIKGÖZ, Ayşe Tuğba (2014), "Kentsel dönüşüm Kentsel, Mekansal, Sosyal Etkileri ve Kamunun Rolü: Ankara Gültepe (Çinçin) Örneği”, Yayımlanmamış Yüksek Lisans Tezi, Gazi Üniversitesi Fen Bilimleri Enstitüsü, Ankara.

AKIN, Emel (2007), “Kentsel Dönüşüm ve Kentsel Rantlar: Ankara Örneği”, Yayımlanmamış Yüksek Lisans Tezi, Ankara Üniversitesi Sosyal Bilimler Enstitüsü, Ankara.

ARTUÇ, Demet (2016), "Kentsel Dönüşüm Sosyal ve Mekansal Etkileri: Fikirtepe Dönüşüm Alanı”, Yayımlanmamış Yüksek Lisans Tezi, Marmara Üniversitesi Fen Bilimleri Enstitüsü, İstanbul.

ATAÖV, Anlı ve OSMAY, Sevin (2007), “Türkiye'de Kentsel Dönüşüme Yöntemsel Bir Yaklaşım”, METU JFA, S.2(24), ss.57-82.

BAYRAM, Ahmet Müfit (2006), “Kentsel Dönüşüm Tartışmaları”, Bülten, S.40, ss.7-11.

BOSTAN, Hakan (2017), “Türkiye'de İç Göçlerin Toplumsal Yapıda Neden Olduğu Değişimler, Meydana Getirdiği Sorunlar ve Çözüm Önerileri”, İstanbul Üniversitesi Coğrafya Dergisi, S.35, ss.1-16.

ÇAKIR, Mimar Nilgün ( 2007), “Günümüz Kent Dinamiklerinin Kentsel Dönüşüme Etkileri”, Yayımlanmamış Yüksek Lisans Tezi, İstanbul Teknik Üniversitesi Fen Bilimleri Enstitüsü, İstanbul.

ÇAVUŞOĞLU, Erbatur (2014), Türkiye Kentleşmesinin Toplumsal Arkeolojisi, Ayrıntı Yayınları, İstanbul.

ÇEKER, Ali ve BELGE, Rauf (2015), "İstanbul'da Kentsel Dönüşüm Kapsamında Gerçekleşen Bir Olgu: Soylulaştırma”, Türk Coğrafya Dergisi, S.65, ss.77-86.

DEMIRKIRAN, Senem (2008), “Türkiye'de Kentsel Dönüşüm Uygulamalarında Yerel Yönetimlerin Rolü: Bursa Büyükşsehir Belediyesi Örneği”, Yayımlanmamış Yüksek Lisans Tezi, Trakya Üniversitesi Sosyal Bilimler Enstitüsü, Edirne.

DOĞAN, Mesut (2014), "Cities Urbanization, Metropolises and Related Problems: The Case of Turkey", Urban and Urbanization (Efe, R., Onay, T.T:, Sharuho, I., Atasoy, E., Bayartan, M. Eds.), St. Kliment Ohridski University Press, Sofia (BULGARIA), ss.374-380.

DOĞAN, Mesut (2018), “Türkiye'de Kentsel Dönüşüm ve Sosyo-Ekonomik Yapı Üzerine Etkileri”, Türk \& İslam Dünyası Sosyal Araştırmalar Dergisi, S.5(18), ss.1-8.

DOĞANAY, Ela (2016), “Türkiye'de Kentsel Dönüşüm Politikaları (2002-2014 Dönümü)”, Yayımlanmamış Yüksek Lisans Tezi, Selçuk Üniversitesi Sosyal Bilimler Enstitüsü, Konya.

DOĞANAY, Serkan ve ALIM, Mete (2016), Türkiye Beşeri ve Ekonomik Coğrafyası, Pegem Akademi Yayınları, Ankara.

ERSAVAŞ, Özlem (2009), “Gecekondu Alanlarının Dönüşümü: Ankara Gültepe Mahallesi Örneği”, Yayınlanmamış Yüksek Lisans Tezi, Ankara Üniversitesi Sosyal Bilimler Enstitüsü, Ankara.

ERTAŞ, Mehmet (2011), “Kentsel Dönüşüm Çalışmalarında Sosyal Boyutun İncelenmesi, Ankara ve Londra Örnekleri”, Selçuk Üniversitesi Teknik-Online Dergi, S.10(1), ss.1-18.

GÖRGÜLÜ, Zekai (2008), “Kentsel Dönüşü ve Ülkemiz”, TMMOB İzmir Kent Sempozyumu Bildiriler Kitabı, İzmir, ss.767-780.

GÖYMEN, Korel (1997), Türkiye’de Kent Yönetimi, Boyut Yayıncılık, İstanbul.

GÜMÜŞBOĞA, Beste (2009), "Katılım ekseninde kentsel dönüşüm: Altındă̆ Aktaş Mahallesi örneği", Yayımlanmamış Yüksek Lisans Tezi, Ankara Üniversitesi Sosyal Bilimler Enstitüsü, Ankara.

HASOL, Doğan (1998), Ansiklopedik Mimarlık Sözlüğü, YEM Yayınları, İstanbul.

İÇDUGU, Ahmet, ERDER, Sema ve GENÇKAYA, Ömer Faruk (2004), Türkiye’nin Uluslararası Göç Politikaları: 1923-2023, Koç Üniversitesi Göç Araştırmaları Merkezi Yayını, İstanbul.

İÇDUYGU, Ahmet ve ÜNALAN, Turgay (1998), "Türkiye'de İçgöç: Sorunsal Alanları ve Araştırma Yöntemleri”, Türkiye'de İçgöç Sempozyumu Bildiriler Kitabı, 6-8 Haziran 1997 - Gerede/BOLU, İstanbul Tarih Vakfi Yayınları, İstanbul, ss.38-55. 
İSLAM, Tolga ve CİRAVOĞLU, Ayşen (2006), "Soylulastırma ve İstanbul”, Mimarist Dergisi, S.6(21), ss.3738.

KALAĞAN, Gökhan ve Çiftçi Salih (2012), “Kamu-Özel Sektör İş Birliğinin Kentsel Mekâna Yansıması: Kentsel Dönüşüm Örneği ve Yeni Aktörler”, Sosyal ve Beșeri Bilimler Dergisi, S.4(2), ss.121-133.

KARPAT, Kemal H. (2003), Türkiye'de Toplumsal Dönüşüm, Kırsal Göç, Gecekondu ve Kentleşme (Çev. Abdulkerim Sönmez), İmge Kitabevi, İstanbul.

KAYA, Eylem (2009), "Kentsel Dönüşüm Projeleri ve Halk Katılımı”, Toplum ve Demokrasi Dergisi, S.3(67), ss.203-216.

KELEŞ, Ruşen (1984), Ketleşme ve Konut Politikası, Ankara Üniversitesi Siyasal Bilgiler Fakültesi Yayınları, Ankara.

KELEŞ, Ruşen (2013), Kentleşme Politikası, İmge Kitabevi, Ankara, 13. Baskı.

KELEŞ, Ruşen ve DURU, Bülent (2008), “Ankara'nın Ülke Kentleşmesindeki Etkilerine Tarihsel Bir Bakış”, Mülkiye Dergisi, S.32(261), ss.27-44.

MEDER, Mehmet ve BAL, Selda (2018), "Soylulaştırma ve Ankara Dikmen Vadisi Örneği", Pamukkale Üniversitesi Sosyal Bilimler Enstitüsü Dergisi, S.32, ss.211-223.

ÖNGÖREN, Gürsel (2017), Kentsel Dönüşüm Hukuku, Öngören Hukuk Yayınları, İstanbul. http://www.ongoren.av.tr/wp-content/uploads/2014/12/Kentsel-donusum-hukuku-14-haziran-2017.pdf (Erişim tarihi: 20.03.2019).

ÖZDEMIR, Ünal (2016), “Türkiye'nin Yerleşme Coğrafyası”, Türkiye Beşeri ve Ekonomik Coğrafyası (Ed. Serkan Doğanay ve Mete Alım), Pegem Akademi, Ankara, ss.61-95.

ÖZDEN, Pelin Pınar (2002), "Yasal ve Yönetsel Çerçevesiyle Şehir Yenileme Planlama ve Uygulaması: Türkiye Örneği”, Yayımlanmamış Doktora Tezi, İstanbul Teknik Üniversitesi Fen Bilimleri Enstitüsü, İstanbul.

ÖZDEN, Pelin Pınar (2006), “Türkiye'de Kentsel Dönüşümün Uygulanabilirliği Üzerine Düşünceler”, İstanbul Üniversitesi Siyasal Bilgiler Fakültesi Dergisi, S.35, ss.215-233.

ÖZGÜR, E. Murat (1995), “Türkiye'deki İç Göçlerde Ankara İlinin Yeri”, Türkiye Coğrafyası Araștırma ve Uygulama Merkezi Dergisi, S.4, ss.63-76.

ÖZGÜÇ, Nazmiye (1988-1992), "Şehirsel Koruma ve Coğrafya”, İstanbul Üniversitesi Coğrafya Dergisi, S.3, ss.61-122.

SEKMEN, Seçil (2007), “Kentsel Dönüşüm Üzerine Bir Model Önerisi: İzmir Ferahlı Mahallesi Örneği”, Yayımlanmamış Yüksek Lisans Tezi, Dokuz Eylül Üniversitesi Fen Bilimleri Enstitüsü, İzmir.

SERTKAYA DOĞAN, Özlem (2009), "Nüfus Coğrafyası Açısından Bir İnceleme: Silivri”, Marmara Coğrafya Dergisi, S.20, ss.1-19.

SERTKAYA DOĞAN, Özlem (2017), "Population Movements In Turkey: Internal Migrations", Current Researches in Geograpy (Ed. H. Arslan, M. A. Icbay, K. Stoychev) International Association of Social Science Research, Bialystok, ss.49-59.

ŞAHİN, Savaş Zafer (2006), "Kentsel Dönüşümün Kentsel Planlamadan Bağımsızlaştırılması/Ayrılması Sürecinde Ankara”, Planlama Dergisi, S.36, ss.111-120.

ŞIŞMAN, Aziz ve KİBAROĞLU, Didem (2009), "Dünyada ve Türkiye'de Kentsel Dönüşüm Uygulamaları", Türkiye Harita Bilimsel ve Teknik Kurultayı Kitabı, TMMOB Harita ve Kadastro Mühendisleri Odası Yayın1, Ankara, ss.1-9.

TDK - TÜRK DIL KURUMU (2019), Güncel Türkçe Sözlük, TDK Yayını, Ankara. http://www.tdk.gov.tr/index.php?option=com_gts\&arama=gts\&guid=TDK.GTS.5a8b64fe8dab23.311420 85 (Erişim tarihi: 20.03.2019).

TEKELİ, İlhan (2011), “Kent, Kentli Hakları”, Kentleşme ve Kentsel Dönüşüm, Tarih Vakfı Yurt Yayınları, İstanbul.

THOMAS, Siân (2003), A Glossary of Regeneration and Local Economic Development, Local Economic Strategy Center, Manchester, UK. 
DOĞAN, Mesut ve BOSTAN, Hakan - Kentsel Dönüşümün Nüfusun Sosyo-Ekonomik Yapısı Üzerindeki Etkileri: Ankara Yenimahalle Örneği

TÜIK - TÜRKIYE İSTATISTIK KURUMU (2019), "İl ve İlçelere Göre, Illillçe Merkezi, Belde/Köy Nüfusu ve Yıllık Nüfus Artışı", E-İstatistik, http://www.tuik.gov.tr/PreTablo.do?alt_id=1059 (Erişim tarihi: 20.03.2019).

YENICE, M. Serhat (2014), “Türkiye’nin Kentsel Dönüşüm Deneyiminin Tarihsel Analizi”, Başakşehir Üniversitesi Fen Bilimleri Enstitüsü Dergisi, S.16(1), ss.76-88.

YENIMAHALLE BELEDIYE BAŞKANLIĞI (?Tarihsiz), Yenimahalle Belediyesi Kentsel Dönüşüm Raporları, Yenimahalle Belediyesi Yayını, Ankara.

YENIMAHALLE BELEDIYE BAŞKANLIĞI (2016), "SODEM'den Yenimahalle'ye Ödül", E-Haber, http://www.yenimahalle.bel.tr/Haber/sodem\%E2\%80\%99den-yenimahalle\%E2\%80\%99ye-odul/34430

(Erişim tarihi: 20.03.2019).

YENIMAHALLE BELEDIYYE BAŞKANLIĞI (2016), Yenimahalle Belediyesi Broşürü, Yenimahalle Belediyesi Yayını, Ankara.

YENIMAHALLE BELEDIYYE BAŞKANLIĞI (2016), "Yenimahalle'de Önce İnsan", E-Haber, http://www.yenimahalle.bel.tr/Haber/yenimahalle\%E2\%80\%99de-once-insan/35699 (Erişim tarihi: 20.03.2019).

YILDIRIM, Aziz (2004), "Kentleşme ve Kentleşme Sürecinde Göçün Suç Olguları Üzerindeki Etkileri", Yayımlanmamış Yüksek Lisans Tezi, Ankara Üniversitesi Sosyal Bilimler Enstitüsü, Ankara.

YAMAN, Murat (2011), “Kentsel Dönüşüm Uygulamalarl Ankara Büyükşsehir Belediyesi: Dikmen Vadisi 3. Etap Örneği”, Yayımlanmamış Doktora Tezi, Ankara Üniversitesi Sosyal Bilimler Enstitüsü, Ankara.

634 sayılı Kat Mülkiyeti Kanunu, (02.07.1965 tarih ve12038 sayılı Resmi Gazete).

775 sayılı Gecekondu Kanunu, (30.07.1966 tarih ve 12362 sayılı Resmi Gazete).

1164 sayılı Arsa Üretimi ve Değerlendirilmesi Hakkında Kanun, (10.05.1969 tarih ve 13195 sayılı Resmi Gazete).

1580 sayıl1 Belediye Kanunu, (14.04.1930 tarih ve 1471 say1lı Resmi Gazete).

1605 sayılı 6785 sayılı İmar Kanununda Bazı Değişiklikler Yapılması Hakkında Kanun, (20.07.1972 tarih ve 14251 sayıl1 Resmi Gazete).

2805 sayılı İmar ve Gecekondu Mevzuatına Aykırı Yapılara Uygulanacak Bazı İşlemler ve 6785 sayılı İmar Kanununun Bir Maddesinin Değiştirilmesi Hakkında Kanun, (21.03.1983 tarih ve 17994 sayılı Resmi Gazete).

2863 sayılı Kültür ve Tabiat Varlıklarını Koruma Kanunu, (23.07.1983 tarih ve 18113 sayılı Resmi Gazete).

2942 sayılı Kamulaştırma Kanunu, (08.11.1983 tarih ve 18215 sayılı Resmi Gazete).

2981 sayılı İmar ve Gecekondu Mevzuatına Aykırı Yapılara Uygulanacak Bazı İşlemler ve 6785 Sayılı İmar Kanununun Bir Maddesinin Değiştirilmesi Hakkında Kanun, (08.03.1984 tarih ve 18335 sayılı Resmi Gazete).

2985 sayılı Toplu Konut Kanunu, (02.03.1984 tarih ve 18344 sayılı Resmi Gazete).

3030 sayılı Büyükşehir Belediyelerin Yönetimi Hakkında Kanun Hükmünde Kararname'nin Değiştirilerek Kabulü Hakkında Kanun, (09.07.1984 tarih ve 18453 sayılı Resmi Gazete).

3086 sayılı Kıyı Kanunu, (01.12.1984 tarih ve 18592 sayılı Resmi Gazete).

3194 sayıl1 İmar Kanunu, (09.05.1985 tarih ve 18749 say1lı Resmi Gazete).

4123 sayılı Tabii Afet Nedeniyle Meydana Gelen Hasar ve Tahribata İlişkin Hizmetlerin Yürütülmesine Dair Kanun, (25.07.1995 tarih ve 22354 sayllı Resmi Gazete).

4650 sayılı Kamulaştırma Kanununda Değişiklik Yapılması Hakkında Kanun, (05.05.2001 tarih ve 24393 say1lı Resmi Gazete).

5104 sayılı Kuzey Ankara Girişi Kentsel Dönüşüm Projesi Kanunu, (12.04.2004 tarih ve 25400 sayılı Resmi Gazete). 
5162 sayılı Toplu Konut Kanununda ve Genel Kadro ve Usulü Hakkında Kanun Hükmünde Kararnamenin Eki Cetvellerin Toplu Konut İdaresi Başkanlığı’na Ait Bölümünde Değişiklik Yapılması Hakkında Kanun, (12.05.2004 tarih ve 25460 sayılı Resmi Gazete).

5216 sayılı Büyükşehir Belediye Kanunu, (23.07.2004 tarih ve 25531 sayılı Resmi Gazete).

5218 sayılı Ankara Belediyesine, Arsa ve Arazisinden Belli Bir Kısmını Mesken Yapacaklara 2490 Sayılı Kanun Hükümlerine Bağlı Olmaksızın ve Muayyen Şartlarla Tahsis ve Temlik Yetkisi Verilmesi Hakkında Kanun, (22.06.1948 tarih ve 6938 say1lı Resmi Gazete).

5228 sayılı Bina Yapımını Teşvik Kanunu, (06.07.1948 tarih ve 6950 sayılı Resmi Gazete).

5366 sayılı Yıpranan Tarihi ve Kültürel Taşınmaz Varlıkların Yenilenerek Korunması ve Yaşatılarak Kullanılması Hakkında Kanun, (05.07.2005 tarih ve 25866 sayılı Resmi Gazete).

5393 sayılı Belediye Kanunu, (13.07.2005 tarih ve 25874 sayıl1 Resmi Gazete).

5431 sayılı Ruhsatsız Yapıların Yıktırılmasına ve 2290 sayılı Belediye Yapı ve Yollar Kanununun 13 üncü Maddesinin Değiştirilmesine Dair Kanun, (11.06.1949 tarih ve 7230 sayılı Resmi Gazete).

5999 sayılı Kamulaştırma Kanununda Değişiklik Yapılmasına Dair Kanun, (30.06.2010 tarih ve 27627 say1lı Resmi Gazete).

6188 sayılı Bina Yapımını Teşvik ve İzinsiz Yapılan Binalar Hakkında Kanun, (29.07.1953 tarih ve 8470 say1lı Resmi Gazete).

6292 sayılı Orman Köylülerinin Kalkınmalarının Desteklenmesi ve Hazine Adına Orman Sınırları Dışına Çıkarılan Yerlerin Değerlendirilmesi ile Hazineye Ait Tarım Arazilerinin Satışı Hakkında Kanun, (26.04.2012 tarih ve 28275 say1l Resmi Gazete).

6306 sayılı Afet Riski Altındaki Alanların Dönüştürülmesi Hakkında Kanun, (31.05.2012 tarih ve 28309 say1lı Resmi Gazete).

6330 sayılı On Üç İlde Büyükşehir Belediyesi ve Yirmi Yedi İlçe Kurulması ile Bazı Kanun ve Kanun Hükmünde Kararnamelerde Değişiklik Yapılmasına Dair Kanun, (06.12.2012 tarih ve 28489 sayılı Resmi Gazete).

6704 sayılı 6306 Sayılı Afet Riski Altındaki Alanların Dönüştürülmesi Hakkında Kanunun Anayasa Mahkemesi Tarafından Iptal Edilen Bazı Maddelerin Yeniden Düzenlenmesini Içeren Kanun, (26.04.2016 tarih ve 29695 say1l Resmi Gazete).

6785 sayılı İmar Kanunu, (16.07.1956 tarih ve 9359 sayılı Resmi Gazete).

7033 sayılı Yeniden (78) Kaza Kurulması ve İzmir Vilayetine Bağı Kuşadası Kazasının Aydın Vilayetine Bağlanması Hakkında Kanun, (27.06.1957 tarih ve 9644 sayılı Resmi Gazete).

7116 sayı1ı İmar ve İskan Vekaleti Kuruluş ve Vazifeleri Hakkında Kanun, (09.05.1958 tarih ve 9906 sayı1lı Resmi Gazete).

7143 sayılı Vergi ve Diğer Bazı Alacakların Yeniden Yapılandırılması ile Bazı Kanunlarda Değişiklik Yapılmasına İlişkin Kanun, (18.05.2018 tarih ve 30425 sayılı Resmi Gazete).

7367 sayılı Hazineden Belediyeye Devredilecek Arazi ve Arsalar Hakkında Kanun, (29.07.1956 tarih ve 10265 say1l1 Resmi Gazete).

327 sayı11 6785 sayı11 İmar Kanununa Geçici Bir Madde Eklenmesi Hakkında Kanun, (12.09.1963 tarih ve 11503 say1l1 Resmi Gazete).

644 sayılı Çevre ve Şehircilik Bakanlığı'nın Teşkilat ve Görevleri Hakkında KHK, (04.07.2011 tarih ve 27984 say1l1 Resmi Gazete).

6306 sayılı Afet Riski Altındaki Alanların Dönüştürülmesi Hakkında Kanunun Bazı Maddelerini Iptal Eden Veya Değiştiren Anayasa Mahkemesi Kararı, (26.07.2014 tarih ve 29072 sayılı Resmi Gazete). 